\title{
Electrospinning of Cyclodextrin Functional Nanofibers for Drug Delivery Applications
}

\author{
Fuat Topuz *(1) and Tamer Uyar *(D) \\ Institute of Materials Science \& Nanotechnology, UNAM-National Nanotechnology Research Center, \\ Bilkent University, 06800 Ankara, Turkey \\ * Correspondence: fuat.topuz@rwth-aachen.de (F.T.); tamer@unam.bilkent.edu.tr (T.U.); \\ Tel.: +90-312-290-8987 (T.U.)
}

Received: 11 July 2018; Accepted: 24 August 2018; Published: 24 December 2018

\begin{abstract}
Electrospun nanofibers have sparked tremendous attention in drug delivery since they can offer high specific surface area, tailored release of drugs, controlled surface chemistry for preferred protein adsorption, and tunable porosity. Several functional motifs were incorporated into electrospun nanofibers to greatly expand their drug loading capacity or to provide the sustained release of the embedded drug molecules. In this regard, cyclodextrins $(\mathrm{CyD})$ are considered as ideal drug carrier molecules as they are natural, edible, and biocompatible compounds with a truncated cone-shape with a relatively hydrophobic cavity interior for complexation with hydrophobic drugs and a hydrophilic exterior to increase the water-solubility of drugs. Further, the formation of CyD-drug inclusion complexes can protect drug molecules from physiological degradation, or elimination and thus increases the stability and bioavailability of drugs, of which the release takes place with time, accompanied by fiber degradation. In this review, we summarize studies related to CyD-functional electrospun nanofibers for drug delivery applications. The review begins with an introductory description of electrospinning; the structure, properties, and toxicology of $\mathrm{CyD}$; and CyD-drug complexation. Thereafter, the release of various drug molecules from CyD-functional electrospun nanofibers is provided in subsequent sections. The review concludes with a summary and outlook on material strategies.
\end{abstract}

Keywords: cyclodextrin; electrospinning; drug delivery; nanofibers; cyclodextrin-inclusion complexes; essential oils; electrospun nanofibers; poly-cyclodextrin; antibacterial; antibiotics

\section{Introduction}

Electrospun nanofibers of synthetic, natural, and hybrid systems have been widely exploited as drug delivery materials due to their high specific surface area, which allows enhanced drug loading and ability to modulate release profiles by structural tuning [1-11]. They can be engineered in various shapes, textures, and sizes with diameters down to a few nanometers. Further, the fiber surface can be modified with specific functional ligands or molecules to hinder them from the nonspecific adsorption of proteins or make them cell adhesive via decoration with cell binding ligands [3,12,13]. Drugs can be loaded into electrospun nanofibers by blending prior to electrospinning or using specific chemistry for the controlled release of drugs from the fiber matrix [14,15]. Although there are many pros of electrospun nanofibers for drug delivery applications, they cannot serve as injectable drug reservoirs. On the other hand, the drug-loaded nanowebs or fiber-deposited meshes are quite promising as wound dressing materials $[11,12]$. Apart from their physical protection to the injured tissue, they can provide the sustained release of the entrapped drugs to achieve wound debridement and wound healing simultaneously [16]. In this regard, comprehensive reviews on the use of electrospun nanofibers for wound healing are available $[16,17]$. Likewise, the use of CyD-based hydrogel materials for wound 
dressing has been reviewed in detail [18]. As most drugs are hydrophobic compounds and thus not intrinsically water soluble, the incorporation of a considerable amount of drug molecules into electrospun nanofibers while maintaining their activity can be problematic. In this context, the use of $\mathrm{CyD}$ enhances the solubility of the embedded drugs while keeping them stable and bioavailable for enhanced therapy results. The drug release can take place as $\mathrm{CyD} / \mathrm{drug} \mathrm{ICs}$, if $\mathrm{CyD}$ are not chemically attached to the material, or by altering the surrounding conditions that lead to entropically unfavorable inclusion complexation.

The use of drug-loaded electrospun mats as implant materials has taken considerable interest in wound healing. The release of the embedded drugs can take place with the degradation of nanofibers. With that, the entrapped drug molecules can be released from the fiber matrix. Particularly, the use of some specific drugs can accelerate wound healing process and reduce pain. Furthermore, the drug release can be tuned by the structure of the fiber components: sustained drug release can be obtained for the electrospun fibers made by hydrophobic polymers or structurally tuned fiber systems. In one example, core-sheath structured nanofibers with core-loading of hydroxycamptothecin (HCPT) were used on mice via intratumoral implantation [19]. The use of hydroxypropyl $\beta$-CyD (HP- $\beta-\mathrm{CyD}$ ) molecules as an additive significantly fastened the HCPT release and allowed the higher degradation of emulsion electrospun fibers. The higher release of the loaded HCPT was ascribed to the distribution pattern of HP- $\beta-\mathrm{CyD}$ and HCPT within the fibers. In another example, CyD inclusion complexes (CyD:ICs) with perfluoroperhydrophenanthrene (PFP) as oxygen carriers to cells seeded on the electrospun scaffolds of poly(carbonate urethane) (PCU) and polycaprolactone (PCL) [20]. The ICs of PFP and CyD significantly increased the amount of the dissolved oxygen. Such a concept can be exploited in in vivo applications to fasten the healing of wounded tissues.

In the electrospinning, the texture, size, and structure of nanofibers can be tailored over electrospinning parameters and polymer formulation [21]. Such control on the fiber structure endows them with enhanced performance in drug loading and allows the sustained release of the embedded drug molecules. In this regard, several polymer-based fiber systems were implemented in drug delivery applications $[1,22]$. Particularly, biocompatible polymers are preferably chosen since they do not release any toxic products during their use. In this regard, polycaprolactone (PCL), poly-L-lactic acid (PLLA), and polycaprolactone/poly(ethylene oxide) (PCL/PEO) are the most widely used polymeric materials [23-26]. The degradation of such nanofibers takes place over hydrolysis, starting from the surface to the core through surface erosion without leaving any toxic byproducts [27]. Along with the fiber degradation, the entrapped drug molecules are released from the fiber matrix. The sustained drug release from such polymers is greatly influenced by the structural features of polymers (e.g., hydrophobicity and glass-transition temperature $\left(T_{\mathrm{g}}\right)$ ) and the type of the used spinneret system. In this context, a comprehensive review on the sustained release of drugs from electrospun nanofibers was reported by Chou et al., in which the release from uniaxial and coaxial nanofibers from various polymers was deliberately discussed [28]. When hydrophilic electrospun nanofibers are used, the degradation mostly follows bulk erosion with the breakage of hydrolytically labile bonds. In other words, the bulk erosion takes place once the water diffusion is much faster than the scaffold degradation, followed by mass loss throughout the bulk of the material [29].

The crucial problems in drug delivery applications are (i) uncontrolled release of drug molecules (i.e., burst release), (ii) unsustainable drug delivery, (iii) low drug loading, and (iv) low stability and bioavailability of drugs. In this regard, the electrospinning can minimize these problems to some extent because of its unique features, including easy to use with tailored-made fiber properties and applicability to a wide range of materials, such as polymers, composites, and ceramics with fiber sizes ranging from nanometer to micrometer. Further, the functionalization of electrospun nanofibers with pharmaceutical excipients, such as $\mathrm{CyD}$, improves their performance in drug delivery applications. CyD comprise unique features that are often desired in drug delivery carriers. For instance, drug molecules can be entrapped into the hydrophobic molecular-environment of $\mathrm{CyD}$ by inclusion-complexation, which dramatically increases the stability of drug molecules under harsh 
conditions, e.g., high temperature, sunlight, and $\mathrm{pH}$ [30]. Further, such complexation remarkably increases their water solubility since many drugs are hydrophobic molecules. Most importantly, for a drug molecule to be pharmacologically active, it should have significant water solubility and lipophilicity to be able to permeate biological membranes through passive diffusion so that no accumulation occurs that can give rise to toxicity. In this regard, lipophilic CyD may assist them in crossing the biological membranes through component extraction or fluidization and can minimize the immunogenic response of body [31]. Further, the surface of the electrospun nanofibers becomes crucial for their in vivo applications since the biocompatibility of the nanofibers and their interactions with the immune system are greatly defined by their surface chemistry. Undesired protein adsorption may occur rapidly when the material is implanted. The adsorbed proteins can denature on hydrophobic surfaces and thus affect the immune system and wound healing. Hence, the surface chemistry becomes a highly critical factor when the fiber mats are intended to be used in in vivo drug delivery.

CyD-functional electrospun nanofibers have been engineered using different approaches. Although most research has been focused on $\mathrm{CyD} /$ drug inclusion-complexes (ICs)-embedded polymeric electrospun nanofibers, the recent decade has witnessed significant advances in the polymer-free electrospinning of $\mathrm{CyD}$ and their use in drug delivery applications. Functional electrospun nanofibers were also produced using poly-cyclodextrin (polyCyD) molecules in the fiber matrix. In this regard, various active agents either with anticancer, antibacterial, antioxidant or anthelmintic properties have been incorporated into such nanofibers and exploited in drug delivery systems. In the first part of this review, some of the intriguing features of $\mathrm{CyD}$ and the mechanism of inclusion-complexation and drug solubility/stability are given. Afterward, several approaches based on CyD-functional nanofibers for drug delivery applications are discussed. The review ends with a future outlook and concluding remarks.

\section{Electrospinning}

Electrospinning is a versatile process that relies on the jetting of a viscous solution or polymer melt under an electrical field [32]. With the evaporation of solvent molecules, the solidified jet is directed to a collector by electrical forces. During the electrospinning, the fiber is subjected to many different forces, including aerodynamic, inertial, gravitational, rheological, and tensile forces $[33,34]$. Once an electrical voltage is applied, free charges in the solution lead to the movement and rapidly transfer a force to the electrospinning solution to flow. In this regard, the surface tension, viscoelasticity, and charge density of electrospinning solutions are the key factors for the formation of electrospun nanofibers. The texture, morphology, and size of the nanofibers depend on the processing parameters and solution properties. Mostly, polymeric solutions were used to produce continuous electrospun fibers due to their high viscosity and the presence of intra- and intermolecular interactions. Sometimes, because of the instability of the jet of polymer solutions, the formation of beaded fibers can be observed [35-37]. However, with increasing viscosity or tailoring other solution parameters, bead-free electrospun nanofibers can be obtained [37]. Further, various additives can be incorporated in the electrospinning solution to produce functional nanofibers.

The fiber stability can be provided using either hydrophobic molecules or cross-linking approaches to attain water-insoluble fiber meshes. The main advantages of the electrospinning process are as follows: (i) easy to operate, (ii) adaptability to various polymeric systems, and (iii) suitability to prepare the nanofibers with various diameters, textures, and structures. Figure 1 shows a general representation of an electrospinning setup together with some important processing parameters and nanofibers in various forms. The presence of additives can lead to nanofibers with different morphologies. Various nanoparticles can be loaded in the electrospinning solutions by blending to yield hybrid fibers, or the thermal treatment of nanofibers impregnated with inorganic or metallic precursors. Using different spinneret systems, hollow, core-shell, and triaxial fiber structures can be obtained. Particularly, the co-axial fibers show better sustained release profiles than uniaxial fiber systems as the outer shell acts as a molecular gate in the transport of drug molecules. The fiber size 
can simply be adapted by the electrospinning parameters or solution conductivity while the solution properties allow the fabrication of ultrafine fibers having diameters in the nanoscale with different morphologies and textures (Figure 1). In general, increasing the polymer concentration, and flow rate causes the formation of larger nanofibers [38]. On the other hand, the fiber diameter decreases with increasing distance between the needle and collector and solution conductivity [38]. In this regard, the addition of salts is a common approach to produce thinner nanofibers for various polymeric systems [39].

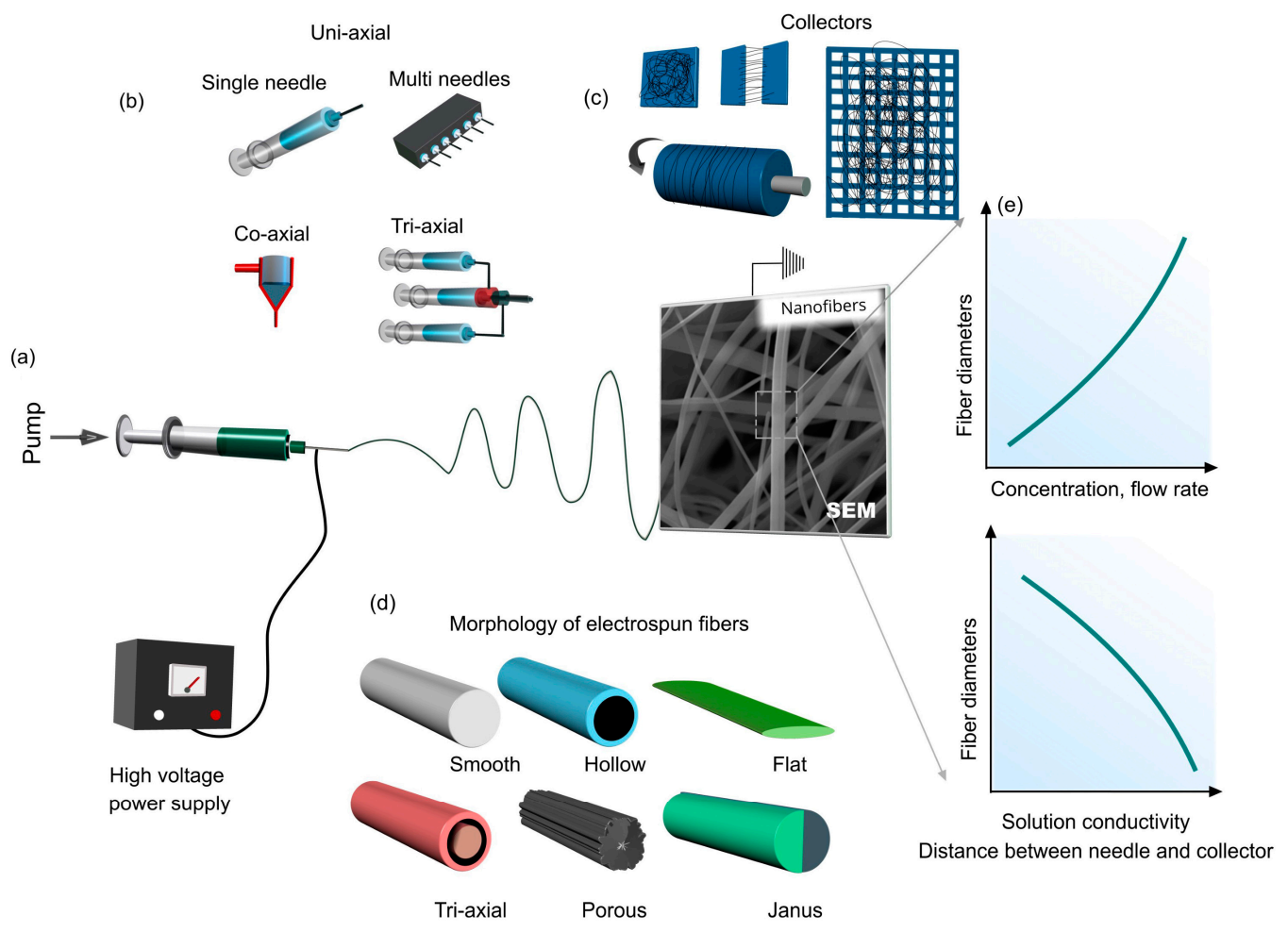

Figure 1. An electrospinning setup with important parameters is shown. (a) A cartoon scheme of an electrospinning system with the scanning electron micrograph of electrospun fibers, (b) common spinneret systems used in electrospinning, (c) collector types, (d) the morphology of electrospun fibers, and (e) diagrams showing the influence of electrospinning process parameters and solution properties on the electrospun fibers.

\section{Cyclodextrins}

Cyclodextrins (CyD) are cyclic oligosaccharides of glucopyranose formed during enzymecatalyzed degradation of starch by glucosyltransferase over chain splitting and intramolecular rearrangement [40]. The molecular structure of CyD resembles a torus-like molecular ring, of which the interior is partially hydrophobic, while the exterior is hydrophilic because of many hydroxyl groups [41]. The inner cavity of CyD accommodates small hydrophobic molecules or portions of large compounds that can fit into their cavities [42]. Owing to their complexation with a wide spectrum of lipophilic molecules, CyD have been implemented in diverse applications, including solubilization enhancers, drug delivery, textile and food industry, tissue engineering, and allied applications [41].

CyD molecules do not elicit an immune response, have low toxicity, and hence are extensively used in bio-related fields, particularly to improve the bioavailability of drugs. In the following section, brief information is provided on the structure, properties, and toxicology of CyD and their inclusion-complexation with guest molecules. 


\subsection{Structure and Properties of Cyclodextrins}

Due to the ${ }^{4} C_{1}$ chair conformation (all equatorial groups in ${ }^{4} C_{1}$ become axial and vice versa) of each glucopyranose unit, $\mathrm{CyD}$ have a shape of a hollow truncated cone, of which the cavity interior has a partial hydrophobic character because of hydrogen atoms of C-3, C-5, and the oxygen atoms of the glycosidic link [43]. Whereas the exterior of CyD is hydrophilic owing to the presence of several hydroxyl groups. Although the existence of numerous CyD with various ring sizes in the class of cycloamyloses, the most common ones are glucose hexamer, heptamer and octamer, which respectively have 6,7 , and 8 glucopyranose units (i.e., $\alpha-C y D, \beta-C y D$, and $\gamma-C y D$ ) (Figure 2). The first reference to $\mathrm{CyD}$ was published in 1891 as the byproduct of bacterial digestion of starch, and at that time it was named as cellulosine [44]. After the exploration of their 3D structure in 1942 by $\mathrm{X}$-ray analysis, they have been considered as complex-forming molecules, and to date, CyD have become common excipients for a diverse range of applications, including pharmaceuticals, foods, agrochemicals, and fragrances [45-48]. Figure 2 shows the molecular structure of a native CyD molecule. The interior size rises from $\sim 5$ to $\sim 8 \AA$ with increasing glucopyranose units from 6 to 8 . Even though all CyD have an identical cavity height of $\sim 7.9 \AA$, the cavity volume shows significant variations from 174 to $427 \AA^{3}$ with increasing the number of glucopyranose units from 6 to 8 .

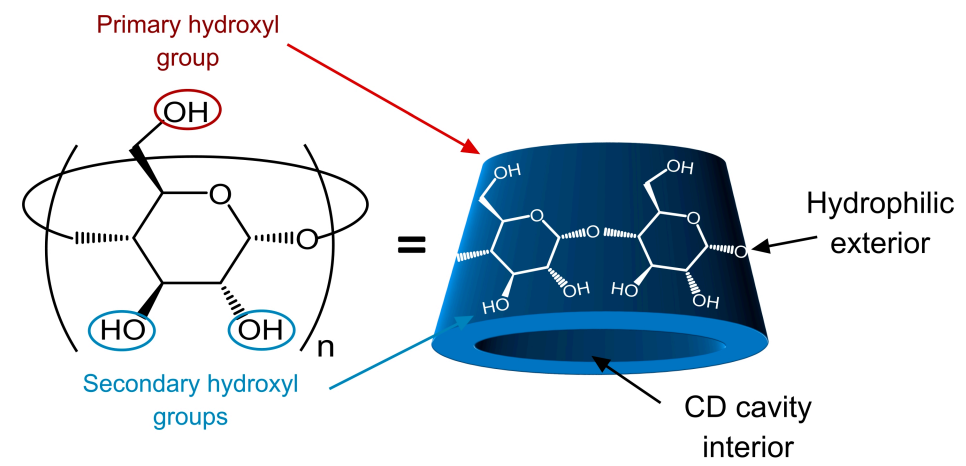

\begin{tabular}{l|ccc} 
& $\alpha$-CyD & $\beta$-CyD & $\gamma$-CyD \\
\hline Number of glucose & 6 & 7 & 8 \\
Molecular weight $(\mathrm{g} / \mathrm{mol})$ & 973 & 1135 & 1297 \\
Water solubility $(\mathrm{g} / \mathrm{L})$ & 145 & 18.5 & 232 \\
Internal diameter $(\AA)$ & $4.7-5.3$ & $6.0-6.5$ & $7.5-8.3$ \\
External diameter $(\AA)$ & 14.6 & 15.4 & 17.5 \\
Cavity volume $\left(\AA^{3}\right)$ & 174 & 262 & 427 \\
Height $(\AA)$ & 7.9 & 7.9 & 7.9 \\
\hline
\end{tabular}

Figure 2. The chemical structure and the representative cartoon illustration of a native cyclodextrin $(\mathrm{CyD})$ molecule in the 3D form. The general characteristics of $\mathrm{CyD}$ are given in the inset table [49].

Due to intermolecular hydrogen bonds, native CyD are not very water-soluble compounds. Particularly, $\beta$-CyD molecule has very limited water solubility $(\sim 18.5 \mathrm{~g} / \mathrm{L})$ while $\alpha$-CyD and $\gamma-\mathrm{CyD}$ molecules have better water solubility at 145 and $232 \mathrm{~g} / \mathrm{L}$, respectively. The poor solubility of $\beta-\mathrm{CyD}$ is originated by the formation of a hydrogen-bond network between the secondary hydroxyl groups [50]. To enhance the water-solubility of the native $\mathrm{CyD}$, they have been chemically modified with different functional groups via amination, esterification, or etherification to break 2-OH-3-OH hydrogen bonds. This also causes the loss of crystallization due to the formation of a statistically substituted material that is made up of many isomeric components with the resultant amorphous, highly soluble end-product. The relatively hydrophobic character of the cavity interior makes CyD ideal molecular carriers of numerous hydrophobic molecules, whose size should be small enough to fit into the cavity. In this 
context, $\mathrm{CyD}$ can form host-guest complexes with a diverse range of organic molecules, inorganic ions, rare gases, and coordination compounds [51-54]. For interested readers, comprehensive reviews on all aspects of CyD and their applications in drug delivery are available [40,55,56].

\subsection{Toxicological Issues of Cyclodextrins}

For their bio-related applications, CyD must possess some critical conditions, such as biocompatibility and biodegradation. CyD are biocompatible pharmaceutical excipients and have found a wide spectrum of biological use. Even though they have many applications, there are some critical remarks that must be taken into account in their in vivo use. CyD are relatively stable molecules against degradation by human enzymes, and, in this regard, it was reported that after intravenous uptake of CyD by humans, they are excreted intact via the kidney. On the other hand, CyD can be degraded by bacterial and fungal enzymes (i.e., amylases), and hence, in the body, CyD are metabolized in the colon before excretion. The toxicity of $\mathrm{CyD}$ arises from their administration route; for instance, for mice exposed to CyD intravenously, the dose that causes $50 \%$ death $\left(\mathrm{LD}_{50}\right)$ is $1.0 \mathrm{~g} / \mathrm{kg}, 0.79$ $\mathrm{g} / \mathrm{kg}$, and more than $4.0 \mathrm{~g} / \mathrm{kg}$ for $\alpha-\mathrm{CyD}, \beta-\mathrm{CyD}$, and $\gamma-\mathrm{CyD}$, respectively $[57,58]$. Particularly, the uptake of high $\beta$-CyD content caused toxicity because of its low water solubility (i.e., 18.5 g/L) [59]. The poor water solubility of $\beta-C y D$ led to microcrystalline precipitation in the kidney. Further, $\beta-C y D$ altered the cell membrane permeability by leading hemolysis because of the binding and extraction of cholesterol through inclusion-complexation [60]. Likewise, Zimmer et al. reported that HP- $\beta-C y D$ interact with cholesterol crystals and dissolve them, which enhance oxysterol production and promote the anti-inflammatory reprogramming of macrophages [61]. Moreover, $\beta-C y D$ damage renal cells by the extraction of cholesterol from kidney membrane and lead to nephrotoxicity [62]. In vivo studies showed the insignificant amount of CyD adsorbed from the intestinal tract in intact form. The major part of orally administered $\mathrm{CyD}$ is metabolized in the colon, and the primary metabolites are further metabolized to $\mathrm{CO}_{2}$ and $\mathrm{H}_{2} \mathrm{O}$. Because of structural differences between native $\mathrm{CyD}$ and $\mathrm{CyD}$ derivatives, the adsorption, distribution, and excretion of $\mathrm{CyD}$ might have different profiles. Even though the oral administration of CyD did not reveal any significant toxicity, some studies reported their adverse effects on long-term parenteral administration. In this regard, Kantner et al. reported subcutaneous long-term administration of HP- $\beta-C y D$ with a daily dose of $200 \mathrm{mg} / \mathrm{kg}$ resulted in increased bone resorption and bone loss [63]. Even at low dosages (50 mg/kg), minor changes in bone metabolism were also observed. The 2-hydroxypropylation of $\beta$-CyD minimizes these toxic effects due to high water solubility of the resultant compound with the condition of less than $1.5 \%$ unmodified $\beta$-CyD presence. The native $\beta$-CyD have been approved in the USA as Generally Recognized as Safe (GRAS) [64]. Likewise, the modified CyD, particularly hydroxypropyl (HP) $\beta$-CyD and sulfobutyl ether (SBE) $\beta-C y D$, are also included in the FDA (Food and Drug Administration) list as approved chemicals for human use [65]. The metabolism of CyD inclusion complexes (ICs) on oral administration of CyD-ICs, they rapidly dissociate, and the guest molecule leaves the cavity [66]. Thereafter, CyD and guest molecules are involved in the normal biological pathway to be metabolized and excreted from the body. Overall, CyD are generally non-toxic chemicals and can potentially be used for many different biological applications.

\subsection{Mechanism of Cyclodextrin Inclusion-Complexation and Drug Solubility}

Many drug molecules are poorly soluble molecules in water and, hence, have affinity to complex with CyD. As the inner cavity of CyD molecules has partial hydrophobic character, they can accommodate small lipophilic molecules into their cavities and significantly enhance their water-solubility via inclusion-complexation. The main driving force of the inclusion-complexation relies on hydrophobic interactions between guest molecules and the CyD cavity. Further, other forces, such as van der Waals and dipole-dipole interactions may also be involved in the inclusion-complexation $[67,68]$. The outer surface of CyD forms hydrogen bonds with water to make them water-soluble. In the inclusion-complexation, intermolecular interactions occur between 
CyD and guest molecules as partial or the complete penetration of a guest molecule into the CyD cavity. Figure 3a depicts a guest molecule entrapped in the CyD cavity, driven by inclusion-complexation. The inclusion-complexation may also occur in diverse ways as shown in Figure 3a. Depending on the conditions, one guest molecule can complex with two CyD molecules or vice versa (i.e., two guest molecules with one $\mathrm{CyD}$ ). The interaction between $\mathrm{CyD}$ and guest molecule is in an equilibrium directed by an equilibrium constant $\left(K_{\mathrm{c}}\right)$. Figure $3 \mathrm{~b}$ displays the phase solubility plot for guest molecules, where the increased solubility is associated with the CyD concentration. Each line highlights the type of inclusion-complex (IC) formed, as well as its stoichiometry. Linear line (shown in pink color (i)) represents the formation of soluble IC, while the line in orange color (ii) depicts the formation of IC with limited solubility.

(a)

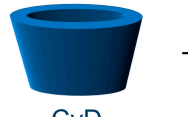

CyD

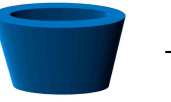

CyD
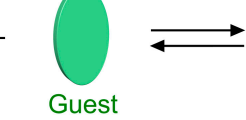

$$
\text { Inclus }
$$

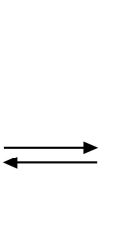

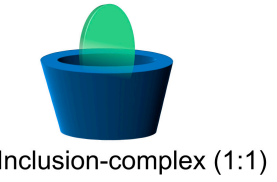

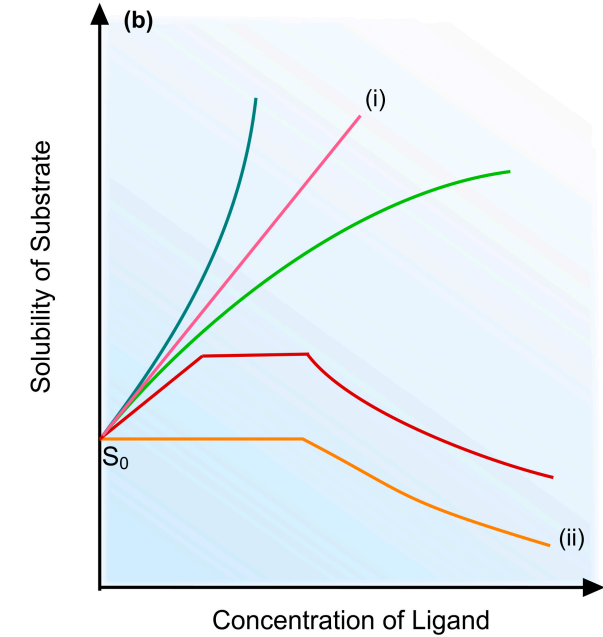

Figure 3. (a) The inclusion complex formation between $\mathrm{CyD}$ and guest molecules at various stoichiometries. (b) The plot shows a phase solubility of guest molecules; (i) represents the formation of soluble inclusion-complex (IC), and (ii) denotes the formation of IC with limited solubility.

Many studies have reported that the inclusion-complexation is governed by van der Waals, electrostatic forces, hydrophobic interactions, hydrogen bonding, and the release of conformational strain [43,69-71]. Some parameters define the strength and relative stability of the complexation. Particularly, the size of cavity and guest molecule, the presence of modified groups in the CyD structure, polarity, and substitution groups on the guest molecule, and environmental conditions, such as medium, ionic strength, and temperature, are prominent factors that can affect the relative strength of inclusion-complexation [72,73]. Normally, a CyD molecule exists in a hydrated form in water-that is, CyD cavity accommodates many water molecules. In the presence of a guest molecule, the replacement between high-energy water molecules and a hydrophobic guest is favored because of an energetically unfavored state of water molecules in the hydrophobic cavity, [41,74]. In general, $\alpha-\mathrm{CyD}$ forms complexes with aliphatic chains and molecules (e.g., PCL and poly(ethylene glycol) (PEG)) [75-77], whereas larger cavity of the $\beta-C y D$ allows host-guest complexes with aromatic rings, such as polycyclic aromatic hydrocarbons (PAHs) [78,79] and essential oils [80,81].

\subsection{Drug Stability and Release from Cyclodextrin Inclusion Complexes}

One of the currently important issues in drug delivery is the stability of drug molecules on exposure to some harsh conditions. Particularly, biological drugs are sensitive because of their limited stability upon oral administration and during subsequent circulation. They have low bioavailability and short therapeutic half-lives [82]. In this regard, the CyD cavity is enrolled as a shield to protect them from degradation and increase their bioavailability. CyD are stable molecules and can maintain their 
torus-like molecular structure even at basic $\mathrm{pH}$ values [83]. Further, the pyrolysis of CyD molecules starts over $300{ }^{\circ} \mathrm{C}$, implying their thermal stability at high temperature conditions [84]. The inner cavity of $\mathrm{CyD}$ molecules accommodates various hydrophobic small molecules and increases their thermal stability. In this regard, various volatile substances (e.g., essential oils) were treated with CyD molecules to form inclusion-complexes for extending their shelf-lives [85,86]. Major benefits of CyD in their drug delivery are (i) increasing the water solubility, stability and bioavailability, (ii) reducing the evaporation of volatile active agents, (iii) low degree of hemolysis, and (iv) avoiding admixture incompatibilities [50].

Hydrophobic and van der Waals interactions are the main dominant driving forces for inclusioncomplexation [87]. Therefore, the stability of CyD-ICs is highly dependent on the surrounding conditions that influence these interactions: if $\mathrm{pH}$, ionic strength and temperature of the medium change, guest molecules may leave the CyD cavity because of an energetically unfavored state [72]. This can also be achieved by altering other conditions, making CyD-IC thermodynamically unfavorable.

\section{Cyclodextrin Functional Electrospun Nanofibers for Drug Delivery Systems}

Various CyD-functional electrospun nanofiber-based materials have been reported as drug delivery systems. These include the blending of polymers with $\mathrm{CyD} / \mathrm{drug} \mathrm{IC}$ and using CyD-based polymers with drugs. Further, the electrospun nanofibers of only CyD/drug ICs were also performed without the requirement of a polymeric carrier. Due to the absence of a polymeric component, such nanostructured materials present high loading of active agents complexed with CyD for their use in drug delivery. In the following sections, we subcategorize CyD-functional electrospun nanofibers by means of their route of preparation.

\subsection{Cyclodextrin-Drug Encapsulated Electrospun Polymeric Nanofibers for Drug Delivery Applications}

This is the simplest method to engineer drug-encapsulated electrospun nanofibers through the blending of components (i.e., CyD, drug and polymeric matrix). Generally, CyD and drug are mixed to form inclusion complexes (ICs), and then, blended with the polymer solution, of which the electrospinning produces drug-encapsulated nanofibers. The inclusion-complexation with CyD motifs significantly enhances the water solubility of drug molecules so that high loading capacities can be achieved. In this regard, the Uyar research group reported naproxen (NAP)-CyD ICs loaded PCL nanofibers [88]. Naproxen (NAP), a non-steroidal anti-inflammatory drug, is used in the treatment of pain, inflammation, and fever $[89,90]$. Due to its lipophilic nature, it is practically insoluble in water at low $\mathrm{pH}$, while it becomes soluble at high $\mathrm{pH}$. To make them water-soluble under mild conditions, their ICs were prepared by slowly adding $\beta-C y D$ into the aqueous solution of NAP, and the solution was stirred overnight in water until it became cloudy. Thereafter, the solution was freeze-dried, and IC powder was obtained. The complexation between CyD and NAP significantly enhanced the water solubility of NAP. The ICs were mixed with PCL solution and electrospun to form nanofibers. The mean diameter of PCL nanofibers slightly increased from $\sim 335$ to $\sim 390 \mathrm{~nm}$ with the incorporation of NAP- $\beta$-CyD ICs. The release studies showed enhanced release of NAP from NAP- $\beta-C y D$ ICs encapsulated PCL nanofibers when compared to the pristine NAP-loaded PCL nanofibers prepared in the absence of CyD. Likewise, Akduman et al. reported naproxen-CyD embedded polyurethane nanofibers and observed that the complete release of NAP from the only polyurethane fiber matrix took $120 \mathrm{~h}$ while the use of $\beta-\mathrm{CyD}$ or $\mathrm{HP}-\beta-\mathrm{CyD}$ reduced the delivery time for NAP to $\sim 36$ and $5 \mathrm{~h}$, respectively [91]. The difference in the release profiles from both CyD was due to the solubility difference of $\beta-C y D$ and HP- $\beta-C y D ; H P-\beta-C y D$ has much higher water solubility than the unsubstituted $\beta-\mathrm{CyD}$.

The Uyar research group also reported hydroxypropyl cellulose (HPC) nanofibers impregnated with sulfisoxazole/CyD ICs [92]. Sulfisoxazole (SFS) is a sulfonamide drug with antibiotic properties [93]. Because of its low water solubility (i.e., $<0.1 \mathrm{~g}$ per $100 \mathrm{~mL}$ ), it was mixed with HP- $\beta-C y D$ to form inclusion-complexation, which significantly increased the water solubility of SFS 
for enhanced therapy results. Thereafter, ICs were mixed with HPC, and the resultant mixture was electrospun to obtain ultrafine nanofibers. The IC-loaded nanofibers had a mean fiber diameter of $60 \pm 25 \mathrm{~nm}$, while sole SFS-loaded nanofibers (i.e., produced in the absence of CyD) sized $90 \pm 40 \mathrm{~nm}$, suggesting the use of ICs as an additive reduced the fiber diameter. However, the incorporation of IC did not make any significant impact on the fiber morphology. Although the initial release of SFS from the fiber matrix was fast, the complete release process took $12 \mathrm{~h}$. The inclusion-complexation increased the release rate of SFS than those released from the HPC fiber matrix in the absence of CyD. Further, a sandwich-like fiber system was engineered by placing HPC/SFS/HP- $\beta$-CyD-IC nanofibers between PCL nanowebs. This nanofiber system slowed the release rate of SFS than the fiber prepared without PCL nanofibers. Tonglairoum et al. reported clotrimazole (CZ) loaded nanofibers through electrospinning [94]. A multicomponent fiber system containing CZ-loaded polyvinylpyrrolidone (PVP)/hydroxypropyl- $\beta$-cyclodextrin (HP- $\beta$-CyD) was prepared, and the fiber surface was coated with chitosan-cysteine (CS-SH)/poly(vinyl alcohol) (PVA) to increase the mucoadhesive properties and achieve the sustained release of $\mathrm{CZ}$ from the nanofibers. CZ-loaded nanofibers were successful in killing Candida significantly faster than the commercially used CZ lozenges at 5, 15, and 30 min and were safe for $2 \mathrm{~h}$ incubation. The release profiles of the embedded CZ did not show significant variations, and $80-90 \%$ release was observed after $480 \mathrm{~min}$. Overall, the nanofibers showed promising results in the treatment of oral candidiasis.

Voriconazole (VRC) is a triazole antifungal agent loaded as ICs with HP- $\beta-C y D$ into poly(vinyl alcohol) (PVA) nanofibers and used for ophthalmic delivery [95]. The VRC-loading capacity could be enhanced with increasing CyD content. The total release of VRC took about $8 \mathrm{~h}$ from the nanofibers. Ocular irritation tests were performed on rabbit samples, and the Draize eye test results revealed that there was no ocular discomfort after the administration of the VRC nanofibers and VRC solution, suggesting that VRC-loaded PVA/HP- $\beta-C y D$ composite nanofibers are promising non-irritant materials. Siafaka et al. reported voriconazole-loaded PCL nanofibers in the presence of $\beta-C y D$ [96]. The ICs of VRC and $\beta-C y D$ were mixed with PCL solution and electrospun to form nanofibers. VRC with various concentrations (5-20 wt.\%) were loaded into nanofibers. All nanofibers showed an initial burst release of the VRC over $80 \%$. The burst release was decreased with increasing VRC content. The nanofibers showed antifungal properties with the inhibition of Candida albicans. Opanasopit and co-workers reported fast releasing polyvinylpyrrolidone (PVP)/CyD composite nanofibers for the taste-masked meloxicam [97]. Meloxicam (MX) is a nonsteroidal anti-inflammatory drug molecule that is intended to be used in treating rheumatoid arthritis [98]. CyD molecules were blended to improve the fiber stability. MX was mixed with the CyD, and then PVP solution, of which the electrospinning led to nanofibers. In another CyD-based drug delivery system, electrospun mats were developed using PVP and HP- $\beta-C y D / M X$ ICs [99]. MX was mixed with CyD molecules and electrospun in the presence of PVP in different solvent systems (dimethylformamide (DMF) and ethyl alcohol (EtOH)). HP- $\beta$-CyD molecules significantly improved the solubility of MX. A fast disintegration time and the burst release of MX were observed in an EtOH-based system. Furthermore, EtOH-based fiber system rapidly dissolved in the mouth. Cytotoxicity tests showed that the EtOH-system was much safer than the DMF-based system. Overall, the study showed a composite fiber of PVP and HP- $\beta$-CyD is ideal for fast-dissolving drug delivery to increase palatability of dosage forms.

Recently, Monteiro et al. reported tetracycline/ $\beta-C y D$ IC loaded PCL nanofibers [100]. Tetracycline (TCN) is a common drug used for periodontal disease treatment [101]. After the preparation of TCN/ $\beta-C y D$ ICs, they were incorporated in PCL solution and electrospun to form nanofibers. The half of the embedded-TCN released as a burst from the matrix and then a slow release profile was observed. Total release of the entrapped TCN took $350 \mathrm{~min}$. The nanofibers showed antimicrobial activity against Aggregatibacter actinomycetemcomitans and Porphyromonas gingivalis. TCN was also released in a sustained manner from CyD-free electrospun fibers of PCL/Zein [102,103] and PCL/poly(ethylene-co-vinyl acetate) (PEVA) [104,105]. The incorporation of PCL into the zein fibers slowed the release rate of TCN. TCN release could also be tuned by multi-layered electrospun fibrous 
mats. In this regard, Alhusein et al. showed that the sustained release of TCN from triple-layered fibers of PCL and PEVA when TCN loaded PEVA fibers were used in the middle covered by TCN-free PCL fibers from both sides [105]. This dramatically reduced the burst release of TCN, demonstrating the importance of drug localization on the release profile. In this context, a detailed review on the controlled release of drugs, including TCN, from PCL-based fibers was reported by Blagbrough and colleagues [106]. Chen and coworkers used silk-fibroin based electrospun nanofibers impregnated with HP- $\beta-$ CyD as the carrier of Tamoxifen [107]. Tamoxifen (TAM) is a selective estrogen receptor modulator and acts as antiestrogen by binding to the estrogen receptors to inhibit the growth of the malignant mammary tumors in some tissues [108]. It is also effective in patients with ER-positive metastatic breast cancer [109]. TAM was mixed with HP- $\beta-C y D$ molecules to form ICs to make it water-soluble. Thereafter, the solution was mixed with silk-fibroin and electrospun to form composite fibers. The inclusion-complexation significantly decreased the fiber diameter. The effective loading of TAM was confirmed by the Raman analysis of the fibers. The release results showed that the TAM first dissociated from the ICs, and then, was subsequently released from the fiber matrix. The release occurs slowly, and 50\% release was observed after two weeks of incubation, suggesting that the presented concept can be intended as a promising local drug delivery system for breast cancer therapy. Souza et al. recently reported PCL nanofibers impregnated with $\beta$-CyD-silver sulfadiazine ICs [110]. Silver sulfadiazine (SAg) pertains to a sulfanilamide class of chemicals and is known for its topical antimicrobial properties, and is commonly used for the treatment of infected burns [111]. After inclusion-complexation with $\beta-\mathrm{CyD}$, the solution was electrospun in acetic acid to form fibers, whose diameters showed great variations depending on the components; the solution of $15 \mathrm{wt}$ \% PCL led to nanofibers with a mean diameter $358 \mathrm{~nm}$, while IC-loaded PCL nanofibers possessed a mean diameter of $892 \mathrm{~nm}$, suggesting the IC incorporation led to a dramatic increase in the fiber diameter. The release studies showed that, after one day, ca. $80 \%$ of SAg was released from CyD-free PCL fibers, while the respective value was $66 \%$ from the IC-loaded PCL fibers. The nanofibers demonstrated antibacterial properties against $S$. aureus and E. coli.

Core-shell electrospun nanofibers impregnated with CyD functionalities have also been investigated in drug delivery applications. Generally, co-axial nanofibers promoted the sustained release of the entrapped drugs than the uniaxial fibers. In this regard, the Uyar research group reported the preparation of the core-shell nanofibers of curcumin/CyD IC and polylactic acid (PLA) [112]. The core of the nanofibers was IC of CyD and curcumin (CUR), while the shell layer was PLA. The formation of core-shell fiber structure was confirmed by TEM analysis with a contrast difference on the fibers. The slow release of CUR was achieved by core-shell nanofiber structure and the inclusion-complexation of CUR with HP- $\beta-C y D$ provided high solubility. The embedded CUR showed antioxidant activity on the scavenging of 2,2-diphenyl-1-picrylhydrazyl (DPPH) radicals. CUR was also loaded into poly(vinyl alcohol) (PVA) nanofibers in a form of their complexes with CyD molecules [113]. The in vitro studies showed rapid diffusion of curcumin in the first hour followed by slower release. The nanofibers with low CUR loads showed faster release profiles. Another curcumin-loaded nanofiber system with multifunctional additives was developed using poly (L-lactic acid-co- $\varepsilon$-caprolactone) (PLACL) and Aloe Vera (AV), MgO nanoparticles, curcumin and $\beta$-CyD as a candidate material for breast cancer therapy [114]. These multifunctional nanofibers were tested with Michigan Cancer Foundation-7 (MCF-7) breast cancer cells. Depending on the fiber constituents, the proliferation of MCF-7 cells showed a clear decrease by $66 \%$ in PLACL/AV/MgO/CUR with respect to $\mathrm{PLACL} / \mathrm{AV} / \mathrm{MgO}$ nanofibrous scaffolds on day 9. The results demonstrated that $1 \%$ CUR interacting with $\mathrm{MgO}$ nanoparticles exhibited higher inhibition of MCF-7 cells among all other nanofibrous scaffolds, demonstrating their effectiveness for breast cancer therapy. Another PLLAbased nanofibers with CyD functionalities were prepared for the release of hydroxycamptothecin (HCPT) [115]. HCPT is an antitumor drug with poor water solubility, which restricts its use in clinical applications. The solution of PLLA and PEG was mixed with HP- $\beta-C y D$ and HCPT and electrospun into nanofibers whose diameters slightly decreased from 780 to $700 \mathrm{~nm}$ in contrast to those 
nanofibers prepared in the absence of CyD and HCPT. The homogenous distribution of HCPT in the fiber matrix was confirmed by confocal analysis. The release studies revealed the initial burst release of ca. $15 \%$, followed by a gradual release over 20 days. Increasing the HCPT content boosted the release percentage while the addition of higher CyD content minimized the burst release of HCPT. Recently, Masoumi et al. reported ciprofloxacin/CyD-encapsulated PCL nanofibers [116]. Ciprofloxacin (CIP) is an antibiotic drug molecule with poor water solubility and low dissolution rate, which limit its bioavailability [117]. CIP was mixed with $\alpha-C y D$ or $\beta-C y D$ to form ICs and thereafter added to PCL solution. The electrospinning of these composite mixtures led to bead-free electrospun nanofibers loaded with CIP. The release tests were performed at $\mathrm{pH}=7.2$, and the released CIP content showed variations depending on the CyD-type and the preparation route of ICs; sonication-driven IC-loaded PCL fiber showed better release rate than those prepared without sonication. This can be ascribed to a higher amount of CIP entrapped in the CyD cavity under sonic energy.

The ICs of antifungal drug griseofulvin (GSV) [118], antipsychotic drug (aripiprazole) [119] and phytochemical (asiaticoside) [120] with CyD were also mixed with various polymeric matrices and electrospun to form drug-loaded nanofibers. The Uyar research group reported allyl isothiocyanate loaded PVA nanofibers and investigated their antibacterial properties [121]. The ICs of antibacterial agent allyl isocyanate (AITC) and $\beta-C y D$ were loaded into the electrospun nanofibers of PVA. CyD molecules significantly stabilized AITC during the electrospinning because of inclusion-complexation. The release experiments were performed at three different temperatures $\left(30,50\right.$ and $\left.75{ }^{\circ} \mathrm{C}\right)$ in gas phase, and the release was dramatically increased with higher temperature. The nanofibers showed antibacterial properties with the significant inhibition of E. coli and S. aureus. AITC/CyD ICs were also embedded in the electrospun nanofibers of soy protein isolate (SPI), PEO or PLLA [122]. Fiber morphologies were affected by the AITC concentration used. The AITC release was negligible under dry conditions but increased dramatically as relative humidity rose. Luo et al. reported CyD functional polymeric nanofibers for sequential release of vascular disrupting and chemotherapeutic agents from electrospun nanofibers [123]. Combretastatin A-4 (CA4) and hydroxycamptothecin (HCPT) were loaded in the nanofibers of poly(ethylene glycol)-polylactide (PELA) in the presence of HP- $\beta$-CyD. The sequential release of CA4 and HCPT could achieve a sequential killing of endothelial and tumor cells. Anthelmintic drugs were also released from $\mathrm{CyD}$ functional electrospun fibers. In this context, Vigh et al. reported flubendazole/HP- $\beta$-CyD IC embedded PVP nanofiber webs with enhanced oral bioavailability [124]. A forty milligram could be released in $15 \mathrm{~min}$, and the administration of the nanofiber system led to an increased plasma concentration profile in rats in contrast to the practically non-absorbable crystalline flubendazole. This can be ascribed to the effect of the embedded CyD, which prevented the crystallization of flubendazole. Doxorubicin (DOX), a chemotherapy medicine, was released from the PLLA nanofibers in the form of their ICs with methylated- $\beta-C y D$ in parallel to their release from CyD-free PLLA fibers [125]. The results showed that the use of CyD molecules led to controlled release, and $17 \%$ decrease in the burst release was observed, followed by a quantifiable sustained release up to two days. Metoclopramide hydrochloride $(\mathrm{MH})$, a drug molecule that has been used to treat nausea and vomiting, was incorporated into HP- $\beta-C y D$ functional PVA nanofibers, and the release of MA was performed in a phosphate buffer $(\mathrm{pH}=6.8)$ at $37^{\circ} \mathrm{C}$ [126]. $90 \%$ Release of MA took place in $1 \mathrm{~min}$ due to burst release of MA. CyD-functional electrospun nanofibers were also used for the delivery of proteins. In one example, $\beta$-lactamase BlaP protein was mixed with the solution of chitosan/PEO containing CyD molecules, and the resultant mixture was electrospun into fibers [127]. CyD were used to increase the protein stability. In the absence of protein, spindle-shaped fibers were formed. However, the protein addition gave rise to smooth, bead-free nanofibers. The activity of the $\beta$-lactamase tested over the hydrolysis of nitrocefin, and enhanced hydrolysis was observed for the CyD functional nanofibers, demonstrating that the embedded CyD stabilized the protein in the fiber matrix.

A blending method was also applied for the preparation of essential oil loaded CyD functional electrospun fibers. Essential oils are plant-derived phytochemicals with antibacterial and antimicrobial properties [128,129]. They have also shown antimutagenic and antifungal activities [130]. Opanasopit 
and colleagues reported plai oil/HP- $\beta$-CyD IC [131] and herbal oil/ HP- $\beta$-CyD IC [132] loaded PVP nanofibers and monitored release profiles of the oil from the fiber matrix. The release of plai oil from the fiber matrix demonstrated burst release and subsequent sustained release over $24 \mathrm{~h}$. The release rate changed between 10 and $30 \%$ in $24 \mathrm{~h}$ depending upon the oil load in the fiber. The release of herbal oil took less than one minute. Lin et al. reported cinnamon essential oil (CEO)/CyD loaded PEO nanofibers [133]. In this regard, first CEO/ $\beta$-CyD proteoliposomes were prepared by using a thin-lipid film evaporation-ultrasonic hydration-freeze and thaw technique. Afterwards, they mixed with PEO and electrospun to form bead-free nanofibers (Figure 4A). The CEO release studies were performed in ethanol, and the amount of CEO released from the fiber matrix was measured by GC-MS. In the presence of Bacillus cereus, the release of CEO was significantly enhanced. The CEO release from the nanofibers was about $30 \%$ in $96 \mathrm{~h}$, whereas this increased to $80 \%$ in the presence of B. cereus. A similar effect was observed at higher temperature, which enhanced the release rate of CEO (Figure 4C). The resultant nanofibers showed significant inhibition against the growth of $B$. cereus due to the antibacterial property of CEO.
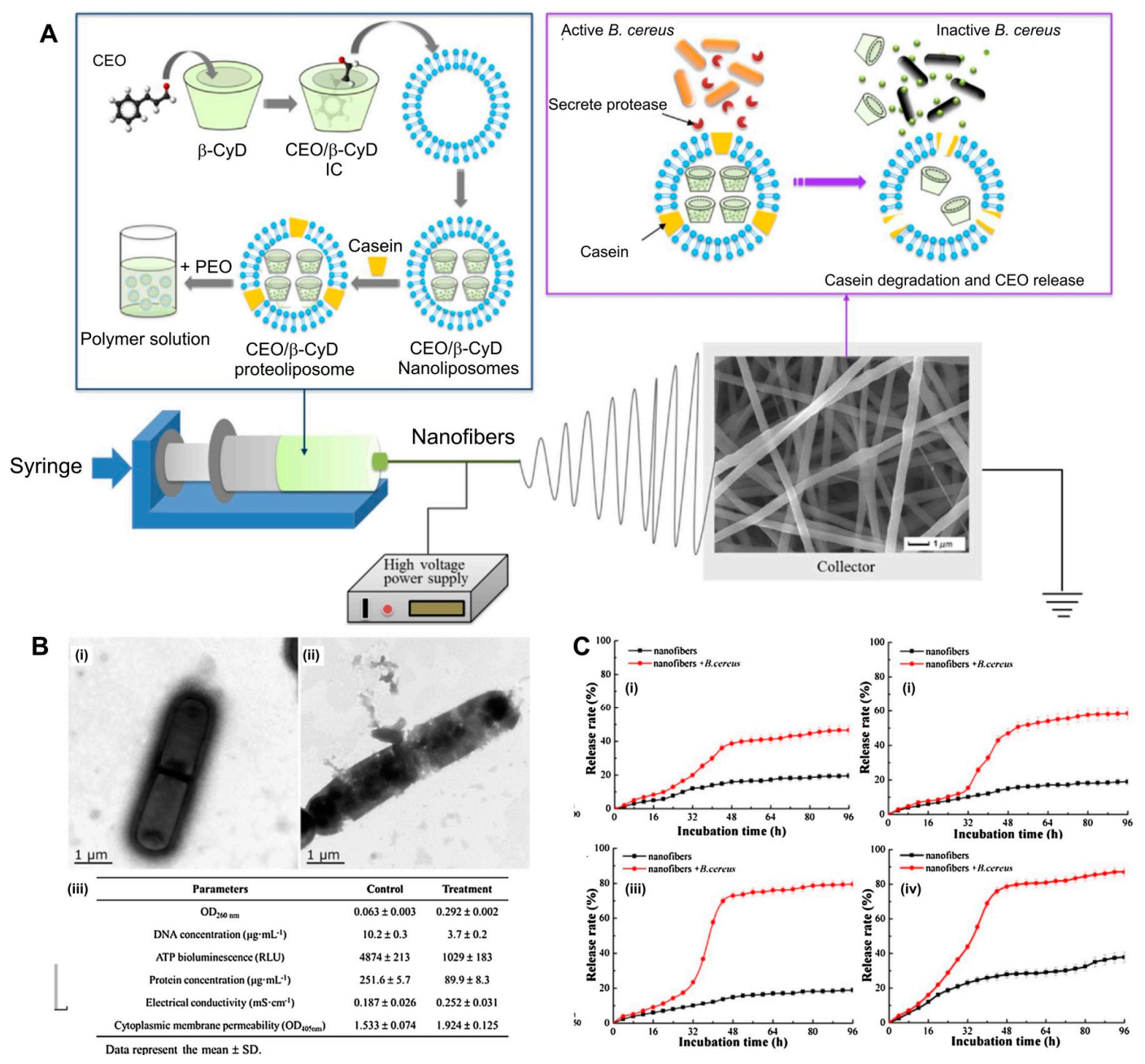

Figure 4. (A) Cartoon schemes of the production of $C E O / \beta-C y D$ proteoliposomes incorporated poly(ethylene oxide) (PEO) fibers and B. cereus proteinase triggered cinnamon essential oil (CEO) delivery from $\mathrm{CEO} / \beta-\mathrm{CyD}$ proteoliposomes. (B) TEM images of B. cereus before (i) and after the treatment (ii) of $\mathrm{CEO} / \beta-\mathrm{CyD}$ proteoliposomes. (iii) The respective analysis results on the release of $B$. cereus cell constituents and the cell membrane permeability before and after proteoliposomes treatment. (C) The release rate of $\mathrm{CEO} / \beta-\mathrm{CyD}$ proteoliposomes nanofibers stored at different temperatures $4{ }^{\circ} \mathrm{C}$ (i), $12{ }^{\circ} \mathrm{C}$ (ii), $25^{\circ} \mathrm{C}$ (iii), and $37^{\circ} \mathrm{C}$ (iv) for 4 days. The figure was reproduced from [133] with the permission of Elsevier, 2017. 
The cinnamon essential oil (CEO) was also encapsulated in PVA/ $\beta$-CyD nanofibers, and in this context, the ICs of cinnamon and $\beta-\mathrm{CyD}$ were mixed with PVA solutions and electrospun to form nanofibers with a mean diameter of $240 \pm 40 \mathrm{~nm}$ [134]. CyD molecules notably increased the thermal stability of CEO after complexation. Due to the intrinsic antimicrobial property of CEO, the nanofibers exhibited strong antimicrobial activity against $E$. coli and S. aureus. Furthermore, the entrapment in fiber systems prolonged the shelf-life of CEO. Cinnamon/ $\beta$-CyD ICs were also loaded into PLLA fibers, and the nanofibers showed antimicrobial properties [135]. The same research group also reported an identical fiber system using lysozyme as an additive and observed the enhancement of the antimicrobial activity of cinnamon essential oil-loaded electrospun nanofilm by the incorporation of lysozyme [136]. Recently, Munhuweyi et al. reported that cinnamon and oregano essential oils-loaded PVA-CyD nanofibers [137]. The ICs of essential oils with $\beta-C y D$ molecules were prepared and mixed PVA solutions, of which the electrospinning led to nanofibers varying between 120 and $180 \mathrm{~nm}$ in diameter depending on essential oil loading. Liu et al. reported cinnamaldehyde/CyD loaded PLLA fibers via electrospinning [138]. Cinnamaldehyde (CA) pertains to the class of essential oils and is known for its antibacterial and antioxidant properties [139]. The ICs of the $\beta-C y D$ and CA were mixed with PLA and electrospun into fibers of 4-6 $\mu \mathrm{m}$ depending on the IC loading. Increasing IC content in the PLLA fiber decreased water contact angle because of many $\mathrm{OH}$ groups. Increasing IC content led to high release percent of the embedded CA. In the first $20 \mathrm{~h}$, a significant increase of CA was observed, but afterwards, almost no change on the release profile was monitored. The CA-loaded fibers showed antibacterial properties against E. coli and S. aureus. Likewise, ultrafine nanofibers from zein impregnated with the ICs of eucalyptus essential oil (EEO) and $\beta$-CyD were produced by electrospinning [140]. The ICs of EEO and $\beta$-CyD were prepared by co-precipitation technique and added to aqueous ethanol solutions of zein. The electrospinning of the mixtures led to the formation of bead-free nanofibers. The IC-loaded zein nanofibers showed $24 \%$ greater reduction of growth than pure zein fibers. For Listeria monocytogenes, the growth reduction was $28.5 \%$, and for Staphylococcus aureus, it was $24.3 \%$.

PLLA was also used as a carrier of gallic acid (GA)/CyD ICs [141]. The IC of GA with HP- $\beta$-CyD molecules was prepared and mixed with PLLA solutions whose electrospinning led to bead-free nanofibers. The release studies were performed in aqueous solution of $\mathrm{EtOH}$ and increased GA release was observed with increasing $\mathrm{EtOH}$ content. The release came to equilibrium after $4 \mathrm{~h}$. The nanofibers showed antioxidant activity in the scavenging of DPPH radicals. Mascheroni et al. reported perillaldehyde-loaded pullulan nanofibers functionalized with $\beta$-CyD [142]. The blending of pullulan and $\beta-\mathrm{CyD}$ with embedded perillaldehyde was performed and electrospun. The release of volatile perillaldehyde showed a profound effect of RH on the release profile.

The Uyar research group has reported several studies related to the encapsulation of CyD ICs of volatile active agents such as essential oils (e.g., eugenol [85], geraniol [86]) or fragrance/flavor molecules (e.g., menthol [143-145], vanillin [146]) into electrospun polymeric nanofibers in order to enhance the temperature stability and shelf-life of such volatile active agents. Likewise, hexanal, a naturally occurring volatile compound, released from CyD-functional xanthan fibers. The CyD-functional xanthan fibers showed faster release of hexanal than pure xanthan fibers [147]. Moreover, a type of vitamin E ( $\alpha$-tocopherol), an antioxidant, was incorporated into PLLA nanofibers after its complexation with $\gamma$-CyD molecules [148]. The PLLA $/ \alpha$-tocopherol $/ \gamma$-CyD nanofibers showed antioxidant properties. The Uyar research group has also reported $\beta$-CyD/quercetin ICs loaded poly(acrylic acid) (PAA) nanofibers [149]. The electrospinning of the mixture of PAA, $\beta-\mathrm{CyD}$ and quercetin led to well-tuned nanofibers with a mean diameter of $270 \mathrm{~nm}$. The nanofibers showed a burst release of almost all quercetin molecules. The nanofibers showed antioxidant activity due to the embedded quercetin. Kingshott and colleagues reported retinyl acetate (RA) release from $\beta$-CyD functional PVA nanofibers [150]. The ICs of $\beta$-CyD and RA were incorporated into PVA nanofibers to enhance the shelf-life and thermal stability of RA. The release of RA was very slow, reaching $90 \%$ after 3 months. The general overview of the $\mathrm{CyD} / \mathrm{drug}$ ICs loaded polymeric electrospun nanofibers was summarized in Table 1, where the composition of the fiber matrix and drug molecules were given, along with release data. 
Table 1. General overview of CyD/drug ICs embedded polymeric electrospun nanofibers used in drug delivery.

\begin{tabular}{|c|c|c|c|c|}
\hline CyD Type & Polymer Additive & Active Molecule & Release Data & Ref \\
\hline$\beta-C y D$ & PCL & Naproxen (NAP) & Higher NAP release with CyD & [88] \\
\hline$\beta-C y D, H P-\beta-C y D$ & Pellethane (TPU) & Naproxen (NAP) & $\begin{array}{c}10 \mathrm{~h} \text { (NAP-TPU), } 32 \mathrm{~h} \\
(\mathrm{NAP} / \beta-\mathrm{CyD} / \mathrm{TPU}), 120 \mathrm{~h}(\mathrm{NAP}, \\
\text { HP- } \beta \text {-CyD/TPU) }\end{array}$ & [91] \\
\hline $\mathrm{HP}-\beta-\mathrm{CyD}$ & $\begin{array}{l}\text { Hydroxypropyl } \\
\text { cellulose (HPC) }\end{array}$ & Sulfisoxazole (SFS) & $\begin{array}{c}720 \mathrm{~min} \\
\text { (PCL-PCL-HPC/SFS/HP- } \beta-C y D-I C-N F), \\
>720 \mathrm{~min} \\
(\mathrm{HPC} / \mathrm{SFS} / \mathrm{HP}-\beta-\mathrm{CyD}-\mathrm{IC}-\mathrm{NF})\end{array}$ & [92] \\
\hline $\mathrm{HP}-\beta-\mathrm{CyD}$ & $\begin{array}{c}\text { PVP, PVA, } \\
\text { Thiolated chitosan } \\
\text { (CS-SH) }\end{array}$ & Clotrimazole (CZ) & For all nanofibers $80 \%$ in $480 \mathrm{~min}$ & [94] \\
\hline $\mathrm{HP}-\beta-\mathrm{CyD}$ & PVA & $\begin{array}{l}\text { Voriconazole } \\
\text { (VRC) }\end{array}$ & $8 \mathrm{~h}$ for $100 \%$ release & [95] \\
\hline$\beta-C y D, H P-\beta-C y D$ & PVP & Meloxicam (MX) & $\begin{array}{l}\text { For all nanofibers, } 20 \text { min for } 100 \% \\
\text { release }\end{array}$ & [97] \\
\hline $\mathrm{HP}-\beta-\mathrm{CyD}$ & PVP & Meloxicam (MX) & Rapid release $(<10 \mathrm{~min})$ & [99] \\
\hline$\beta-C y D$ & PCL & Tetracycline (TCN) & $\begin{array}{l}\text { Drug release occurred up to } \\
2 \text { weeks }\end{array}$ & [100] \\
\hline $\mathrm{HP}-\beta-\mathrm{CyD}$ & Silk fibroin (SF) & Tamoxifen (TAM) & $\begin{array}{c}10 \% \text { in } 22 \text { days in PBS, } 50-60 \% \text { in } \\
\text { PBS-EtOH ( } 30 \%) \text { in } 22 \text { days })\end{array}$ & [107] \\
\hline$\beta-C y D$ & PCL & $\begin{array}{l}\text { Silver sulfadiazine } \\
\text { (SAg) }\end{array}$ & $\begin{array}{l}80 \% \text { release from } \mathrm{PCL} / \mathrm{SAg}, 66 \% \\
\text { release from PCL } / \mathrm{SAg} / \beta-\mathrm{CyD}\end{array}$ & [110] \\
\hline $\mathrm{HP}-\beta-\mathrm{CyD}$ & PLLA & Curcumin (CUR) & $\begin{array}{l}\text { Higher release at } \mathrm{pH} \text { of } 1 . \mathrm{CyD} \\
\text { increased drug release. }\end{array}$ & [112] \\
\hline$\beta-C y D$ & PVA & Curcumin (CUR) & $\begin{array}{l}\text { Higher drug content increased the } \\
\text { release rate. }\end{array}$ & [113] \\
\hline$\beta-C y D$ & $\begin{array}{l}\text { Poly (L-lactic } \\
\text { acid-co- } \varepsilon \text {-caprolactone } \\
\text { (PLACL) }\end{array}$ & Curcumin (CUR) & $\begin{array}{l}\text { 1\% CUR interacting with } \mathrm{MgO} \\
\text { nanoparticles showed higher } \\
\text { inhibition of breast cancer cells. }\end{array}$ & [114] \\
\hline $\mathrm{HP}-\beta-\mathrm{CyD}$ & $\begin{array}{l}\text { Poly(DL-lactic } \\
\text { acid)-poly(ethylene } \\
\text { glycol) (PELA) }\end{array}$ & $\begin{array}{l}\text { Hydroxycamptothecin } \\
\text { (HCPT) }\end{array}$ & $\begin{array}{l}\text { Higher CyD content increased } \\
\text { release rate. The release was slow } \\
\text { and took many weeks. }\end{array}$ & [115] \\
\hline $\begin{array}{c}\alpha-C y D \\
\text { and } \beta-C y D\end{array}$ & PCL & Ciprofloxacin & $\begin{array}{l}\text { Higher release with initial higher } \\
\text { drug loading }\end{array}$ & [116] \\
\hline SBE- $\beta-C y D$ & PEO & Aripiprazole (ARP) & Rapid release in $2 \mathrm{~min}$ & [119] \\
\hline $\mathrm{HP}-\beta-\mathrm{CyD}$ & Cellulose acetate & Asiaticoside (AC) & $\begin{array}{l}\text { Higher release with CyD and } \\
\text { initial burst release within } 300 \text { min }\end{array}$ & [120] \\
\hline$\beta-C y D$ & PVA & $\begin{array}{l}\text { Allyl } \\
\text { isothiocyanate } \\
\text { (AITC) }\end{array}$ & $\begin{array}{l}\text { Higher release at } 75^{\circ} \mathrm{C} \text { and } \\
\text { followed by } 50 \text { and } 30^{\circ} \mathrm{C} \text {. }\end{array}$ & [121] \\
\hline$\beta-C y D$ & PEO & $\begin{array}{l}\text { Allyl } \\
\text { isothiocyanate } \\
\text { (AITC) }\end{array}$ & $\begin{array}{l}\text { Higher release with increasing } \\
\text { relative humidity }\end{array}$ & [122] \\
\hline $\mathrm{HP}-\beta-\mathrm{CyD}$ & $\begin{array}{l}\text { Poly(ethylene } \\
\text { glycol)-polylactide } \\
\text { (PELA) }\end{array}$ & $\begin{array}{l}\text { Combretastatin A-4 } \\
\text { (CA4) and } \\
\text { hydroxycamptothecin } \\
\text { (HCPT) }\end{array}$ & $\begin{array}{l}\text { Sustained release of CA4 over } 30 \\
\text { days, fibers showed significant } \\
\text { antitumor efficacy and tumor } \\
\text { vasculature destruction }\end{array}$ & [123] \\
\hline $\mathrm{HP}-\beta-\mathrm{CyD}$ & PVP & Flubendazole & $\begin{array}{l}\text { The release of a dose of } 40 \mathrm{mg} \text { in } \\
\qquad 15 \mathrm{~min}\end{array}$ & [124] \\
\hline $\mathrm{M}-\beta-\mathrm{CyD}$ & PLLA & Doxorubicin (DOX) & $\begin{array}{l}17 \% \text { Decrease in the burst release } \\
\text { was observed and followed by a } \\
\text { quantifiable sustained release up } \\
\text { to } 2 \text { days. }\end{array}$ & [125] \\
\hline $\mathrm{HP}-\beta-\mathrm{CyD}$ & PVA & $\begin{array}{l}\text { Metoclopramide } \\
\text { hydrochloride } \\
\text { (MH) }\end{array}$ & Burst release: $90 \%$ release in $2 \mathrm{~min}$ & [126] \\
\hline
\end{tabular}


Table 1. Cont.

\begin{tabular}{|c|c|c|c|c|}
\hline CyD Type & Polymer Additive & Active Molecule & Release Data & Ref \\
\hline$\beta-\mathrm{CyD}$ derivative & Chitosan & $\begin{array}{c}\beta \text {-Lactamase BlaP } \\
\text { protein }\end{array}$ & $\begin{array}{l}\text { CyD increased the stability of the } \\
\text { embedded protein }\end{array}$ & [127] \\
\hline $\mathrm{HP}-\beta-\mathrm{CyD}$ & PVP & Plai oil & $\begin{array}{l}\text { The release rate ranged was in the } \\
\text { order of } 10 \%>20 \% \sim 30 \% \text { plai oil } \\
\text { within } 24 \mathrm{~h} \text {. }\end{array}$ & [131] \\
\hline HP- $\beta-C y D$ & PVP & Herbal oil & $\begin{array}{l}\text { Very rapid release: } 50 \% \text { release in } \\
\qquad 1 \mathrm{~min}\end{array}$ & [132] \\
\hline$\beta-C y D$ & PEO & Cinnamon (CEO) & $\begin{array}{l}\text { Controlled release in nanofibers } \\
\text { via bacterial protease. }\end{array}$ & [133] \\
\hline$\beta-C y D$ & PVA & Cinnamon (CEO) & $\begin{array}{c}\text { Nanofibers showed excellent } \\
\text { antimicrobial activity against } \\
\text { E. coli and S. aureus. }\end{array}$ & [134] \\
\hline$\beta-C y D$ & PLA & Cinnamon (CEO) & $\begin{array}{l}\text { High antimicrobial activity due to } \\
\text { released CEO }\end{array}$ & [135] \\
\hline$\beta-C y D$ & PVA & Cinnamon (CEO) & $\begin{array}{l}\text { Stronger antimicrobial activity } \\
\text { with incorporated lysozyme }\end{array}$ & [136] \\
\hline$\beta-C y D$ & Chitosan and PVA & $\begin{array}{l}\text { Oregano and } \\
\text { cinnamon EOs }\end{array}$ & $\begin{array}{l}\text { Lower release of Oregano EO than } \\
\text { CEO }\end{array}$ & [137] \\
\hline$\beta-C y D$ & PLA & $\begin{array}{l}\text { Cinnamaldehyde } \\
\text { (CA) }\end{array}$ & $\begin{array}{l}\text { Higher release with increasing CA } \\
\text { content }\end{array}$ & [138] \\
\hline$\beta-C y D$ & Zein & Eucalyptus EO & $\begin{array}{l}\text { Higher antimicrobial activity with } \\
\text { increasing EEO content }\end{array}$ & [140] \\
\hline $\mathrm{HP}-\beta-\mathrm{CyD}$ & PLA & Gallic acid & $\begin{array}{l}\text { Increasing release rate with CyD } \\
\text { incorporation }\end{array}$ & [141] \\
\hline$\beta-C y D$ & Pullulan & Perillaldehyde & $\begin{array}{l}\text { Higher release with increasing } \\
\text { humidity }\end{array}$ & [142] \\
\hline$\alpha-C y D$ & Xanthan & Hexanal & $\mathrm{CyD}$ increased the release rate & [147] \\
\hline$\gamma-\mathrm{CyD}$ & PLA & $\begin{array}{c}\alpha \text {-Tocopherol } \\
(\alpha-\mathrm{TC})\end{array}$ & $\begin{array}{l}\text { CyD increased higher release of } \\
\qquad-\mathrm{TC} .\end{array}$ & [148] \\
\hline$\beta-C y D$ & PAA & Quercetin & $\begin{array}{l}\text { Nanofibers showed enhanced } \\
\text { release rate than the films }\end{array}$ & [149] \\
\hline$\beta-C y D$ & PVA & $\begin{array}{l}\text { Retinyl acetate } \\
\text { (RA) }\end{array}$ & $\begin{array}{l}\text { Slower release with } \mathrm{CyD} \\
\text { incorporation }\end{array}$ & [150] \\
\hline
\end{tabular}

\subsection{Poly-Cyclodextrin Functional Electrospun Nanofibers for Drug Delivery Systems}

$\mathrm{CyD}$ can be cross-linked or polymerized in controlled or noncontrolled routes to form cyclodextrin based polymeric materials (poly-cyclodextrin (polyCyD)). Further, $\mathrm{CyD}$ can be functionalized with polymerizable groups to produce controlled CyD polymers. The poly-cyclodextrin (polyCyD) was also electrospun to form nanofibers to be used in drug delivery applications. In this regard, Oliveira et al. reported coaxial nanofibers based on polyCyD associated with poly(methacrylic acid) (PMAA) for the release of hydrophilic drug, propranolol hydrochloride (PROP) [151]. The nanofibers were cross-linked with thermal treatment at $170{ }^{\circ} \mathrm{C}$ for $48 \mathrm{~h}$ to obtain water-insoluble polyCyD nanofibers (Figure $5 \mathrm{a}-\mathrm{c}$ ). The biocompatibility of the nanofibers was explored over fibroblast cells, and high cell viability was observed. The interaction between $\mathrm{CyD}$ and drug molecules was explored and found to be spontaneous. The burst release of the encapsulated PROP could be modulated by coaxial electrospinning. Uniaxial nanofibers produced with PMAA/polyCyD $(80: 20 w / w)$ and $(60: 40 w / w)$ released $30 \%$ and $35 \%$ PROP in $8 \mathrm{~h}$, while sole PMAA nanofibers released $100 \%$ dose in $15 \mathrm{~min}$. Further, coaxial nanofibers made by polyCyD/PROP core and a shell of PMAA showed better sustained release. In another study, polyCyD was used for the release of fluconazole from the uniaxial nanofibers of polyCyD mixed with PCL and PVP [152]. The nanofibers were further coated with a hydrophobic poly(hexamethyldisiloxane) (polyHMDSO) for tailoring the fiber dissolution and the respective drug release rate. The coating process 
was performed under mild condition plasma polymerization. Unlike non-coated fibers, which rapidly released the drug payload, polyHMDSO-coated nanofibers prolonged drug releasing time to $24 \mathrm{~h}$. The coated nanofibers were tested with bacteria, and the results showed that they could inhibit the in vitro growth of Candida albicans. Another polyCyD-based electrospun nanofiber system was developed using a polymer of HP- $\beta-\mathrm{CyD} /$ citric acid mixed with chitosan to obtain polyelectrolyte complexes [153]. Triclosan was mixed with polyHP- $\beta$-CyD to form ICs, and thereafter, chitosan was added to the solution. The nanofibers were cross-linked with a treatment at $90{ }^{\circ} \mathrm{C}$ for $4 \mathrm{~h}$ and demonstrated antimicrobial activity against the growth of $S$. aureus and $E$. coli for longer periods of time.

(A)

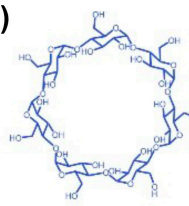
$\beta$-cyclodextrin

(C)

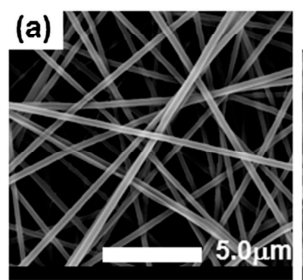

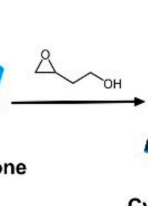

Cyclodextrin polymer
(B)

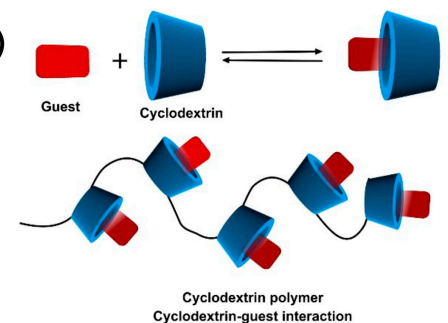

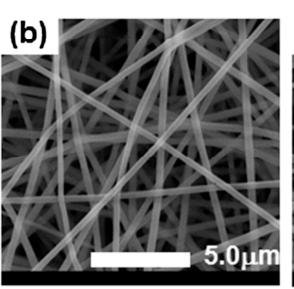
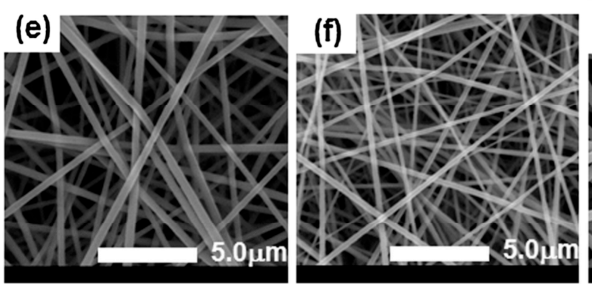

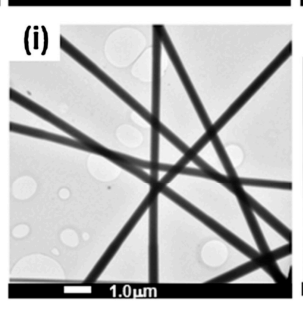

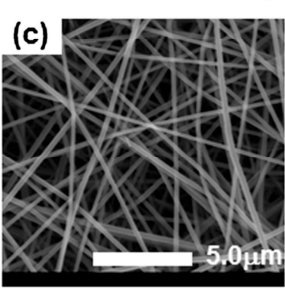
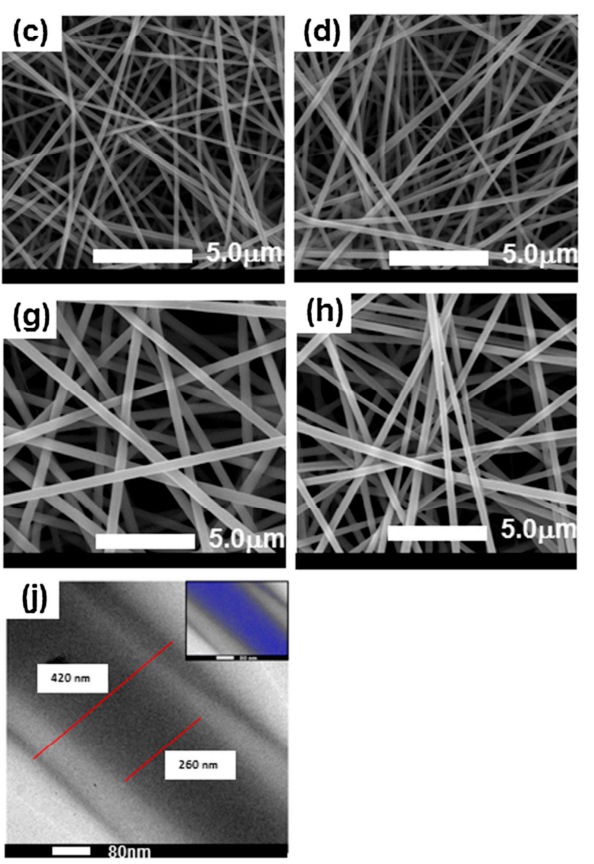

Figure 5. Cartoon schemes of (A) the synthesis pathway of CyD polymers and (B) their complexation with guest molecules. (C) scanning electron microscopy (SEM) and transmission electron microscopy (TEM) images of uni- and co-axial PMAA/polyCyD fibers: (a) SEM uniaxial-PMAA; (b) SEM uniaxial-PMAA + PROP; (c) SEM uniaxial PMAA/polyCyD (80:20); (d) SEM uniaxial PMAA/polyCyD (80:20) + PROP; (e) SEM uniaxial PMAA/polyCyD (60:40); (f) SEM uniaxial PMAA/polyCyD (60:40) + PROP; (g) SEM coaxial-shell (PMAA) and core (polyCyD); (h) SEM coaxial-shell (PMAA) and core (polyCyD + PROP); (i) TEM coaxial-shell (PMAA) and core (polyCyD + PROP); and (j) TEM coaxial-shell (PMAA) and core (polyCyD + PROP). The figure was reproduced from [151] with the permission of Elsevier, 2015.

Hydrophobic CyD-based polymers were also used for drug delivery applications. In this regard, Heydari et al. reported the controlled release of vitamin B2 from hydrophobic peracetyl- $\beta$-CyD polymer (Ac $\beta-C y D P)$ based electrospun nanofibers [154]. Ac $\beta$-CyDP was synthesized by the acetylation of epichlorohydrin functional $\beta-\mathrm{CyD}$ polymer in the mixture of acetic acid and pyridine at $100{ }^{\circ} \mathrm{C}$ for $7 \mathrm{~h}$. The electrospinning of Ac $\beta-C y D P$ in the mixture of acetone and $\operatorname{DMF}(3: 2, v / v)$ led to thin nanofibers, of which the diameters remained nearly stable even with increasing the polymer concentration from 8 to 
$25 \mathrm{wt} . \%$, demonstrating no clear influence of $\mathrm{CyD}$ content on the diameters of the resultant fibers. The cumulative release of vitamin B2 from the fiber matrix was explored at two different $\mathrm{pH}$ values (1.2 and 7.4 ), and the results revealed enhanced release at $\mathrm{pH}=1.2$. The release of vitamin $\mathrm{B} 2$ gradually occurred, and 60 and $40 \%$ of the vitamin diffused out of the nanofibers after $170 \mathrm{~h}$ for the solutions having $\mathrm{pH}$ of 1.2 and 7.4, respectively. Nada et al. used a CyD cross-linked gelatin fiber matrix for the carrier of chloramphenicol [155]. Chloramphenicol is an antibiotic, which may lead to bone marrow suppression and influences red blood cells [156]. The oxidation of $\beta-C y D$ led to polyaldehyde $\beta-C y D$, and it was used to cross-link gelatin. The nanofibers showed antimicrobial activities against Staphylococcus aureus (Gram positive) and Pseudomonas aeruginosa (Gram negative bacteria) and Candida albicans. After two days, the release was as ca. 90\%. A water-insoluble anti-inflammatory drug atorvastatin was loaded in PCL fibers after its complexation with poly-amino-CyD molecules [157]. The quantity embedded was estimated (70-90 $\mu \mathrm{g}$ in $30 \mu \mathrm{m} \times 6 \mathrm{~mm}$ membrane) and the anti-inflammatory effect by cell contact-dependent release reached $60 \%$ inhibition for TNF- $\alpha$ and $80 \%$ for IL-6. Drug delivery electrospun nanofibers were also developed using PVA and carboxymethyl- $\beta-C y D$ grafted chitosan [158]. The carboxymethyl- $\beta-C y D$ was grafted on chitosan by 1-ethyl-3-(3-dimethylaminopropyl) carbodiimide (EDC) and $N$-hydroxysuccinimide (NHS) based coupling. Nanofibers between 130 and $210 \mathrm{~nm}$ in diameter were obtained. The presence of CyD molecules in the nanofibers slowed the release rate of salicylic acid (SA). After an initial burst release of SA, the release percentage reached over $80 \%$ after $24 \mathrm{~h}$. CyD-functional fibers were also produced by the electrospinning of a $\mathrm{CyD}$ functional polymer and an antibiotic drug vancomycin [159]. The CyD-functional polymer was synthesized by poly(ethylene-vinyl alcohol) (pEVOH)/thiol-modified $\mathrm{CyD}$ and a bifunctional cross-linker $\mathrm{N}$-(p-maleimidophenyl) isocyanate (PMPI). The fibers showed the sustained release of vancomycin. CyD-functional polymeric nanofibers were also used to the delivery of a common insect repellent, $\mathrm{N}, \mathrm{N}$-diethyl-3-toluamide (DEET) [160]. Micro-sized fibers with a diameter of $2.8 \pm 0.8 \mu \mathrm{m}$ were obtained by the electrospinning of a water-soluble $\beta$-CyD/pyromellitic dianhydride (PMDA) polymer and thereafter loaded with DEET in diethyl ether. The release data were obtained by TGA analysis, which revealed a sustained release of all DEET in two weeks. The details related to the polyCyD/drug nanofibers for drug delivery were summarized in Table 2.

Table 2. Overview of polyCyD/drug electrospun nanofibers used in drug delivery.

\begin{tabular}{|c|c|c|c|c|}
\hline CyD Type & Polymer Additive & Active Molecule & Release Data & Ref \\
\hline PolyCyD & PMAA & $\begin{array}{l}\text { Propranolol } \\
\text { hydrochloride } \\
\text { (PROP) }\end{array}$ & $\begin{array}{c}40 \% \text { Release (uniaxial PMAA:polyCyD } \\
(60: 40,80: 20), 20 \% \text { release from } \\
\text { coaxial fibers }\end{array}$ & [151] \\
\hline PolyCyD & PCL, PVP & Fluconazole & $\begin{array}{l}\text { Burst release ((FLU-poly- } \alpha-C y D)-I C / P C L \\
\text { and (FLU-poly- } \beta-C y D)-I C / P C L \text { mats } \\
\text { showed a burst of } 85 \% \text { in the first } 15 \mathrm{~min})\end{array}$ & [152] \\
\hline $\mathrm{HP}-\beta-\mathrm{CyD}$ & $\begin{array}{l}\text { Chitosan, citric acid } \\
\text { (as cross-linker) }\end{array}$ & Triclosan & $\begin{array}{l}\text { Higher release at lower } \mathrm{pH}(5.5), 80 \% \\
\text { release in } 10 \mathrm{~h}\end{array}$ & [153] \\
\hline $\begin{array}{l}\text { PolyCyD (peracetyl- } \beta-C y D \\
\text { polymer) }\end{array}$ & - & Vitamin B2 & $\begin{array}{c}60 \%(\mathrm{pH}=1.2) \text { and } 40 \%(\mathrm{pH}=7.4) \text { release } \\
\text { after } 170 \mathrm{~h}\end{array}$ & [154] \\
\hline $\begin{array}{l}\text { Poly aldehyde } \beta-C y D \\
\text { (PA- } \beta-C y D) \text {. }\end{array}$ & Gelatin & Chloramphenicol & $\begin{array}{c}\text { Burst release for gelatin/drug }(90 \% \text { in } 30 \\
\text { min), } 90 \% \text { release in } 48 \text { h for } 7.5 \text { and } \\
10 \text { wt. } \% \text { PA- } \beta-C y D\end{array}$ & [155] \\
\hline Poly-amino- $\beta$-CyD & PCL & $\begin{array}{l}\text { Atorvastatin calcium } \\
\text { trihydrate }\end{array}$ & $\begin{array}{l}\text { TNF- } \alpha \text { inhibition reached about } 60 \% \text { at } 48 \\
\text { h (no dose effect), and up to } 80 \% \text { for IL-6, } \\
\text { depending on the dose }\end{array}$ & [157] \\
\hline $\begin{array}{c}\text { Chitosan grafted } \\
\text { carboxymethyl- } \beta-\mathrm{CyD}(\mathrm{CM} \\
\beta-\mathrm{CyD})\end{array}$ & Chitosan & Salicylic acid & $\begin{array}{c}90 \% \text { after } 24 \text { h at } 37^{\circ} \mathrm{C}, 84 \% \text { after } 24 \mathrm{~h} \\
\text { at } 20^{\circ} \mathrm{C}\end{array}$ & [158] \\
\hline Thiolated CyD & $\mathrm{pEVOH} / \mathrm{sH}-\mathrm{CyD} / \mathrm{PMDI}$ & Vancomycin & Slow release & [159] \\
\hline$\beta-\mathrm{CyD}$ & $\begin{array}{l}\beta-C y D / P M D A \\
\text { polymer }\end{array}$ & \multicolumn{2}{|c|}{$\begin{array}{l}N, N \text {-diethyl-3-toluamide Sustained release of all loaded DEET in } \\
\begin{array}{ll}\text { (DEET) } & 2 \text { weeks. }\end{array}\end{array}$} & [160] \\
\hline
\end{tabular}




\subsection{Polymer-Free Cyclodextrin Electrospun Nanofibers for Drug Delivery Systems}

Drug-loaded electrospun CyD nanofibers can also be prepared without using a polymeric carrier matrix. The electrospinning of polymer-free $\mathrm{CyD} /$ drug IC solutions can produce uniform nanofibers, which are solely based on CyD molecules and their ICs with drug molecules. As these electrospun nanofibers are mostly uncross-linked and hydrophilic, rapid release profiles were observed, along with the fast-dissolving fiber character. The electrospinning of $\mathrm{CyD}$ molecules takes place over their aggregates, which are governed by numerous hydrogen bonds. The Uyar research group has pioneered polymer-free electrospinning of nanofibers from $\mathrm{CyD}$ and $\mathrm{CyD}-\mathrm{IC}$ based systems. The first paper was reported in 2010 [161], and it has been shown that highly concentrated (140-160 wt.\%) solutions of methylated $\beta-\mathrm{CyD}(\mathrm{M}-\beta-\mathrm{CyD})$ molecules either in water or dimethylformamide (DMF) form large aggregates driven by hydrogen bonds, which is the key factor for uniform fiber formation during electrospinning process [161]. In a later study, polymer-free nanofibers were successfully electrospun from three different $\mathrm{CyD}$ derivatives-HP- $\beta-\mathrm{CyD}, \mathrm{HP}-\gamma-\mathrm{CyD}$ and $\mathrm{M}-\beta-\mathrm{CyD}-\mathrm{in}$ three different solvent systems-water, DMF, and dimethylacetamide (DMAc) [162]. The polymer-free nanofibers from native CyD were also produced, in which electrospinning was carried out for $\alpha-C y D$ and $\beta$-CyD in alkaline aqueous systems [83], and $\gamma$-CyD nanofibers were electrospun from a dimethyl sulfoxide (DMSO)/water solvent system [163]. The Uyar research group has also shown that the electrospinning of uniform nanofibers could be produced from CyD-ICs without using a polymer carrier, in which triclosan/CyD ICs system was successfully electrospun into uniform and bead-free nanofibers [164]. In another study, antibacterial properties of electrospun nanofibers from triclosan/CyD IC using two different $\mathrm{CyD}$ derivatives (HP- $\beta-\mathrm{CyD}$ and HP- $\gamma-\mathrm{CyD}$ ) were also reported [165]. Triclosan/CyD ICs electrospun nanofibers showed better antibacterial properties in the inhibition of growth of Gram-negative (E. coli) and Gram-positive (S. aureus) bacteria than pure triclosan.

Essential oils are widely implemented in medical, food, cosmetic, and allied applications due to their antibacterial, antiseptic, antifungal, and antioxidant properties [139]. The Uyar research group has made significant contributions in the fabrication of essential oil loaded CyD functional nanofibers, and several studies related to the polymer-free electrospinning of essential oils/CyD ICs were reported. Since the most of them are slightly water soluble, the use of CyD molecules in the nanofiber form can offer bulk materials loaded essential oils. Very recently, Celebioglu et al. has reported the electrospinning of CyD-camphor IC nanofibers [166]. Camphor-loaded CyD nanofibers rapidly dissolved in water because of their uncross-linked hydrophilic nature. Despite the fact that camphor is a volatile molecule, it can be preserved in the CyD cavity during electrospinning, and the molar ratio after electrospinning was calculated as $\sim 1.00 / 0.65$ and $\sim 1.00 / 0.90$ in HP- $\beta$-CyD/camphor-IC and HP- $\beta-C y D /$ camphor-IC nanofibers, respectively. The camphor release from HP- $\beta$-CyD-IC and $\mathrm{HP}-\gamma$-CyD-IC nanofibers in gas phase was monitored at two different temperatures ( 37 and $75^{\circ} \mathrm{C}$ ) using gas chromatography-mass spectrometry (GC-MS) for $4 \mathrm{~h}$, where the higher temperature enhanced the release rate of camphor because of the diffusion coefficient increment of camphor molecules. Another important essential oil, eugenol, was complexed within CyD nanofibers [167]. The ICs of three cyclodextrin derivatives (HP- $\beta-\mathrm{CyD}, \mathrm{HP}-\gamma-\mathrm{CyD}$, and $\mathrm{M}-\beta-\mathrm{CyD})$ with eugenol were prepared in water and electrospun to form nanofibers. Inclusion-complexation significantly enhanced water solubility and increased the thermal stability of volatile eugenol. Due to their hydrophilic and uncross-linked nature, $\mathrm{CyD}$ nanofibers rapidly dissolve in water. The eugenol-loaded $\mathrm{CyD}$ nanofibers showed a higher antioxidant capacity than eugenol itself, suggesting enhanced antioxidant activity of the fibers than the powder form of eugenol. Essential oils, $p$-cymene and cineole, were also embedded in polymer-free CyD nanofibers in the form of CyD-ICs [168]. Electrospun nanowebs were produced by the ICs of $p$-cymene and cineole with two modified cyclodextrins (HP- $\beta-\mathrm{CyD}$ and HP- $\gamma-\mathrm{CyD}$ ). The thermal stability of both $p$-cymene and cineole increased with inclusion-complexation. On contact, the nanofibers rapidly dissolved in water. Linalool, a natural ingredient of many essential oils, was also loaded into CyD nanofibers as ICs through electrospinning [169]. Well-tuned nanofibers were obtained with antibacterial properties. Antibacterial limonene-loaded polymer-free CyD nanofibers 
were prepared by electrospinning [170]. Modified cyclodextrins (M- $\beta-C y D, H P-\beta-C y D$ and HP- $\gamma-C y D)$ and limonene were mixed to form ICs. The computational and experimental results revealed the molar ratio of the CyD-limonene was 1:1. The released limonene from $\mathrm{M}-\beta-\mathrm{CyD} /$ limonene-IC was less than the nanofibers of HP- $\beta$-CyD/limonene-IC and HP- $\gamma-\mathrm{CyD} /$ limonene-IC due to the higher amount of the preserved limonene in the nanofiber. $25 \%$ limonene was released from $\mathrm{M}-\beta-\mathrm{CyD} /$ limonene-IC nanofibers, whereas the nanofibers of HP- $\beta-\mathrm{CyD} /$ limonene-IC and HP- $\gamma-\mathrm{CyD} /$ limonene-IC released 51 and $88 \mathrm{wt} . \%$ limonene in 100 days, respectively. Inclusion-complexation significantly enhanced the thermal stability of the entrapped active molecules. The nanofibers significantly inhibited the growth of S. aureus and E. coli because of the antibacterial property of limonene. In addition, the nanofibers rapidly dissolved in water because of the polymer-free nature of hydrophilic CyD derivatives. Geraniol-CyD ICs-loaded nanofibers were also reported by the Uyar research group without the requirement of any polymer carrier [171]. Bead-free nanofibers were obtained using three different $\mathrm{CyD}$ types e.g., HP- $\beta-\mathrm{CyD}, \mathrm{M}-\beta-\mathrm{CyD}$, and HP- $\gamma-\mathrm{CyD}$. Even though geraniol is a volatile molecule, it could be preserved in the nanofibers in the range of $\sim 60-90 \%$ depending on formulation parameters. The release studies were either performed at room temperature or short term at high temperature $\left(37,50\right.$, and $\left.75^{\circ} \mathrm{C}\right)$, and the results revealed $\mathrm{M}-\beta$-CyD / geraniol-IC complex loaded nanofibers released less geraniol than the nanofibers of HP- $\beta-\mathrm{CyD} /$ geraniol-IC and $\mathrm{HP}-\gamma-\mathrm{CyD} /$ geraniol-IC, suggesting the strongest inclusion-complexation occurred between $\mathrm{M}-\beta-\mathrm{CyD}$ and geraniol. The nanofibers showed antibacterial properties in the sense of the inhibition of growth of E. coli and S. aureus because of the released geraniol from the fiber matrix. Furthermore, the nanofibers showed enhanced antioxidant activity to those of pure geraniol because of its low water solubility. Likewise, thymol-loaded CyD nanofibers were prepared as ICs of CyD ( $\mathrm{M}-\beta-\mathrm{CyD}, \mathrm{HP}-\beta-\mathrm{CyD}$, and HP- $\gamma$-CyD) [172]. Due to the volatile nature of thymol, it was entrapped in the CyD cavity to enhance its thermal stability. Thymol-loaded CyD nanofibers showed more rapid dissolution in water than hydrophobic thymol. Due to the antioxidant properties of thymol, the respective nanofibers were tested by DPPH radical scavenging, and high scavenging capacity was observed. Polymer-free CyD nanofibers were also electrospun from their ICs with volatile flavor agents e.g., menthol [173] and vanillin [174], and vitamins e.g., vitamin E [175] with enhanced solubility and prolonged shelf-life. Recently, Uyar and colleagues reported the polymer-free electrospinning of carvacrol/CyD ICs [176]. Carvacrol is a phenolic component of plant essential oils and has antioxidant and antimicrobial properties $[177,178]$. The ICs of carvacrol with HP- $\beta-C y D$ or HP- $\beta-C y D$ were electrospun into fibers. These fast dissolving fibers showed enhanced antioxidant activity with an increase content of carvacrol.

In order to develop a fast-dissolving drug/CyD IC nanofibrous system, the ICs of sulfisoxazole (SFS) and sulfobutyl ether $\beta-\mathrm{CyD}\left(\mathrm{SBE}_{7}-\beta-\mathrm{CyD}\right)$ were prepared in water, and thereafter, electrospun into nanofibers in the form of self-standing flexible nanofibrous webs (Figure 6) [179]. In parallel, the ICs of SBE $7-\beta-C y D$ and SFS were prepared as powder. On contact with water, the entrapped SFS was released from the polymer nanofibers, along with the disintegration of the fibers (Figure 7). The polymer-free nanofibers of $S_{B E}-\beta-C y D-S F S$ ICs showed faster dissolution than the powder form of the SBE7- $\beta$-CyD-SFS ICs, and pure SFS was not soluble in water in the absence of CyD (Figure 7). These fast dissolving $\mathrm{CyD}$ functional fiber nanowebs can be implemented if the rapid release of water-insoluble drugs, as the case here with SFS, is desired.

Another fast-dissolving polymer-free fiber system loaded with poorly soluble diclofenac sodium was reported by Balogh et al. [180]. The fibers rapidly dissolved in water (within $2 \mathrm{~min}$ ). Spironolactone, a diuretic drug with antiandrogenic properties, was complexed with $\mathrm{CyD}$ and electrospun into nanofibers without the requirement of any polymeric carrier [181]. The resultant nanofibers rapidly dissolved in water, and the system allowed high loading of lipophilic spironolactone. An interesting CyD based polymer-free fiber system for drug delivery applications was developed using modified $\gamma$-CyD molecules. Yu et al. modified $\gamma$-CyD with phenylacetic acid and performed electrospinning from the mixed solution of dichloromethane (DCM) and dimethylformamide (DMF) $(8: 2, v / v)$ to form fibers (Figure 8) [182]. The bead-free, water insoluble ultrafine fibers with a diameter range of $1-2 \mu \mathrm{m}$ 
were obtained. Unlike other polymer-free CyD fibers, these fibers did not show rapid dissolution. In vitro cell tests revealed the fibers are biocompatible. Several drug molecules (doxorubicin, fluorescein isothiocyanate-dextran (FITC-dextran), recombinant human insulin (FITC-labeled insulin), and chlorin) were loaded by simply incubating the fibers in the solutions of the respective drug molecules. $\sim 50 \%$ of Release of the entrapped drug molecules was observed from the fiber matrix in one month, demonstrating their slow release (Figure 8E). Chlorin-loaded fibers were also exploited for in vivo drug release in mice, and on day 28 , the complete release of chlorin was observed because of the disappearance of its fluorescence signal. The general overview of polymer-free $\mathrm{CD} / \mathrm{drug}$ ICs fibers for drug delivery was summarized in Table 3.

(a)

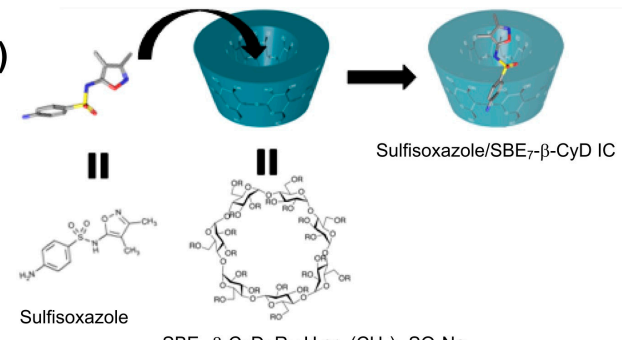

$\mathrm{SBE}_{7}-\beta-\mathrm{CyD} ; \mathrm{R}=\mathrm{H}$ or $-\left(\mathrm{CH}_{2}\right)_{4}-\mathrm{SO}_{3} \mathrm{Na}$
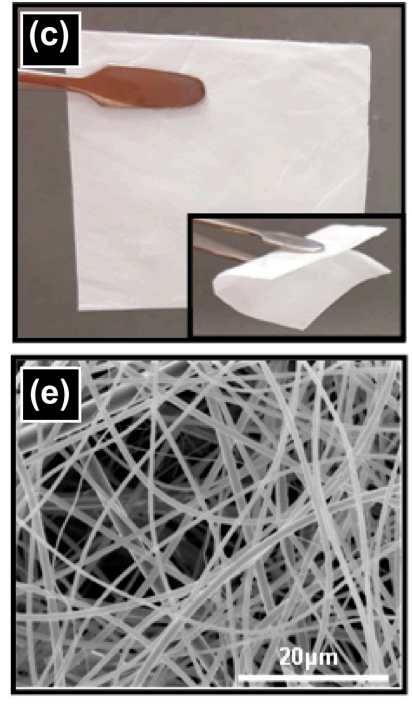
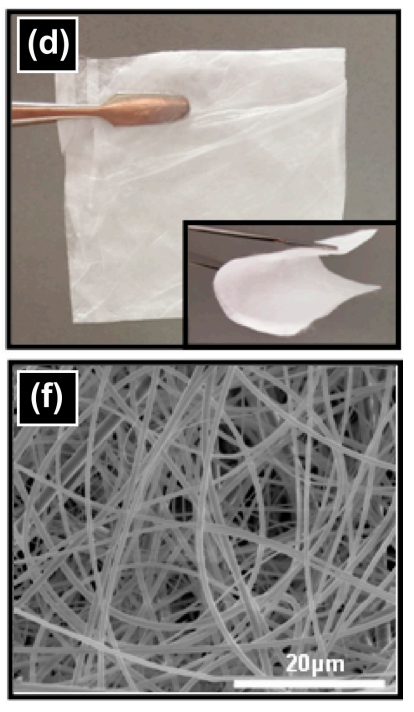

(b)

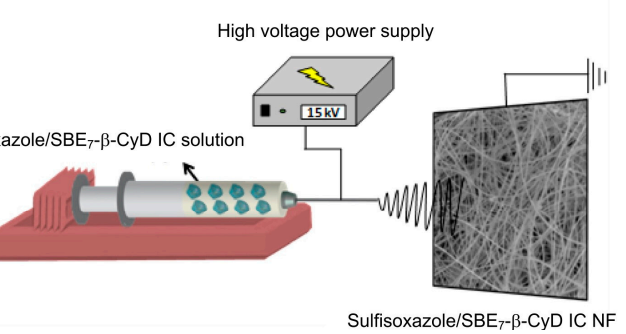

Figure 6. (a) Cartoon illustration of inclusion-complexation between CyD and sulfisoxazole (SFS). The chemical structure of sulfisoxazole and $\mathrm{SBE}_{7}-\beta-\mathrm{CyD}$ with a schematic representation of sulfisoxazole, $\mathrm{SBE}_{7}-\beta-\mathrm{CyD}$ and their IC, (b) schematic representation of the electrospinning of SFS $/ \mathrm{SBE}_{7}-\beta-\mathrm{CyD}-\mathrm{IC}$ NF. Photographs of electrospun (c) SBE $7-\beta-C y D$ nanofibers, (d) SFS/SBE $7-\beta-C y D-I C$ nanofibers, and SEM images of (e) $\mathrm{SBE}_{7}-\beta-\mathrm{CyD} N F$, (f) $S F S / \mathrm{SBE}_{7}-\beta-C y D-I C$ nanofibers. The figure was reproduced from [179] with the permission of Elsevier, 2017. 

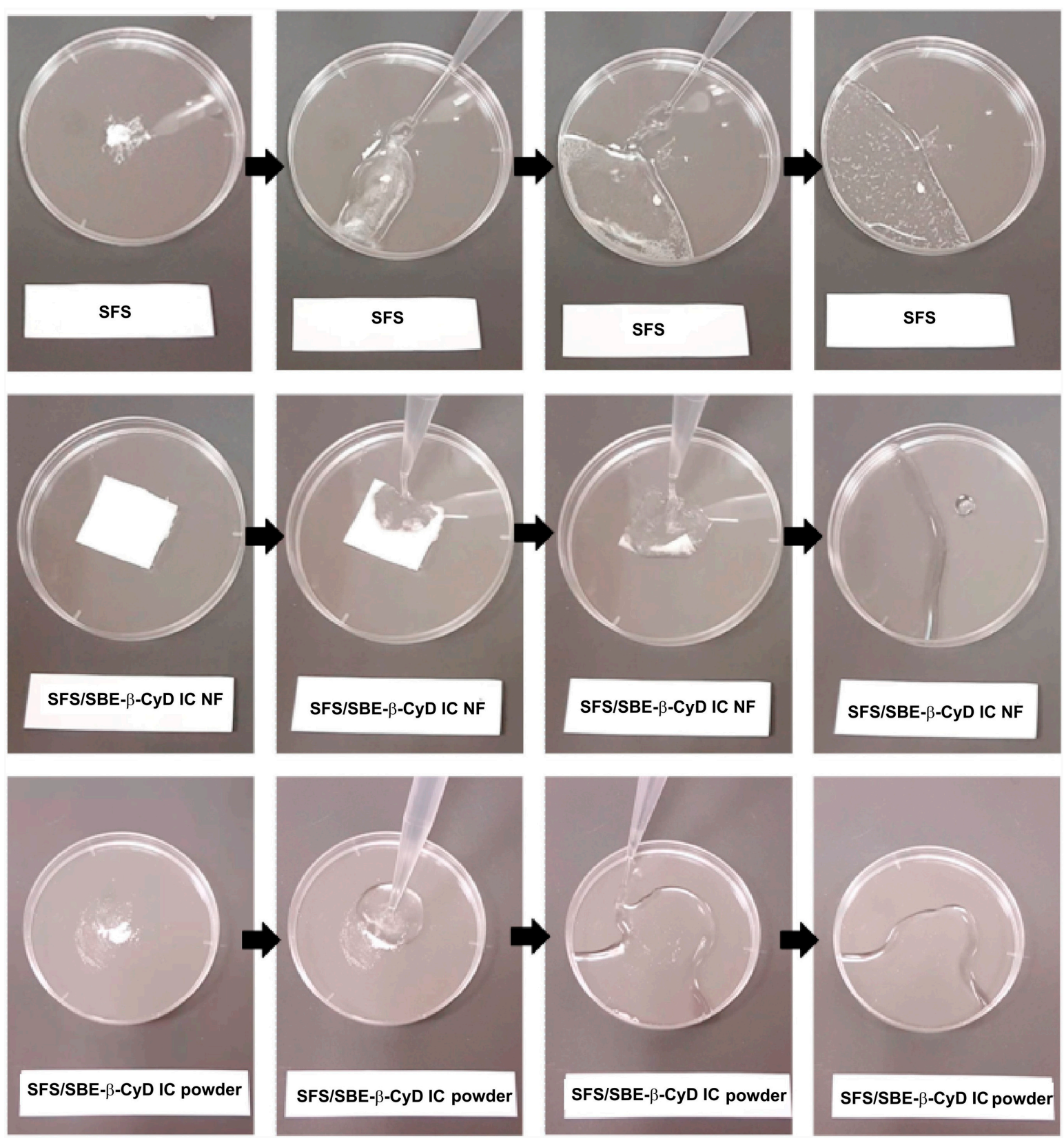

Figure 7. Typical water-solubility of the drug loaded polymer-free $\mathrm{CyD}$ fibers. The representative photos of the SFS and SFS/ SBE $7-\beta-C y D$ IC powder and SFS/ SBE $7-\beta-C y D$ IC nanofibers on exposure to water. The figure was reproduced from [179] with the permission of Elsevier, 2017. 

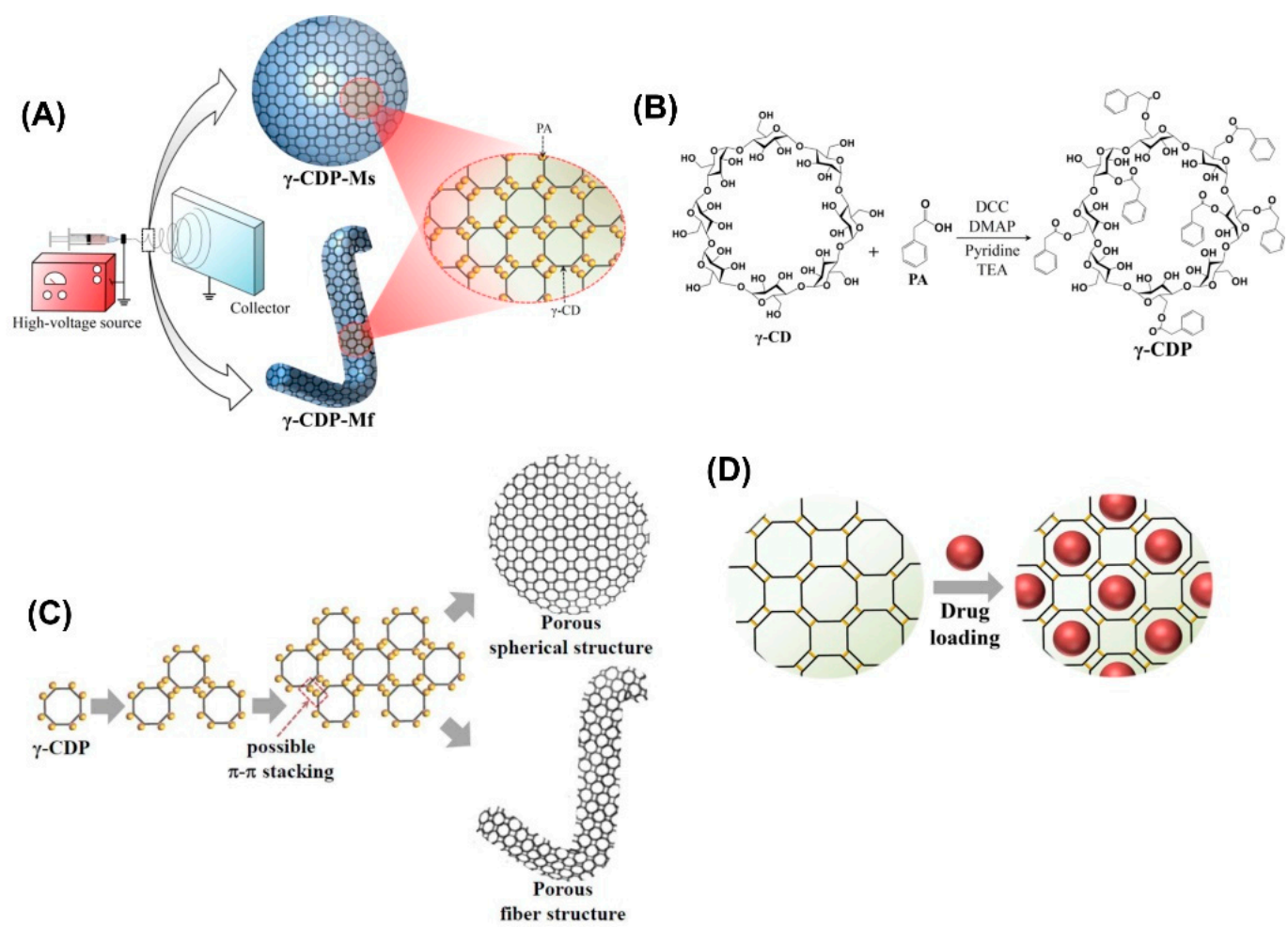

(D)

(E) (i)
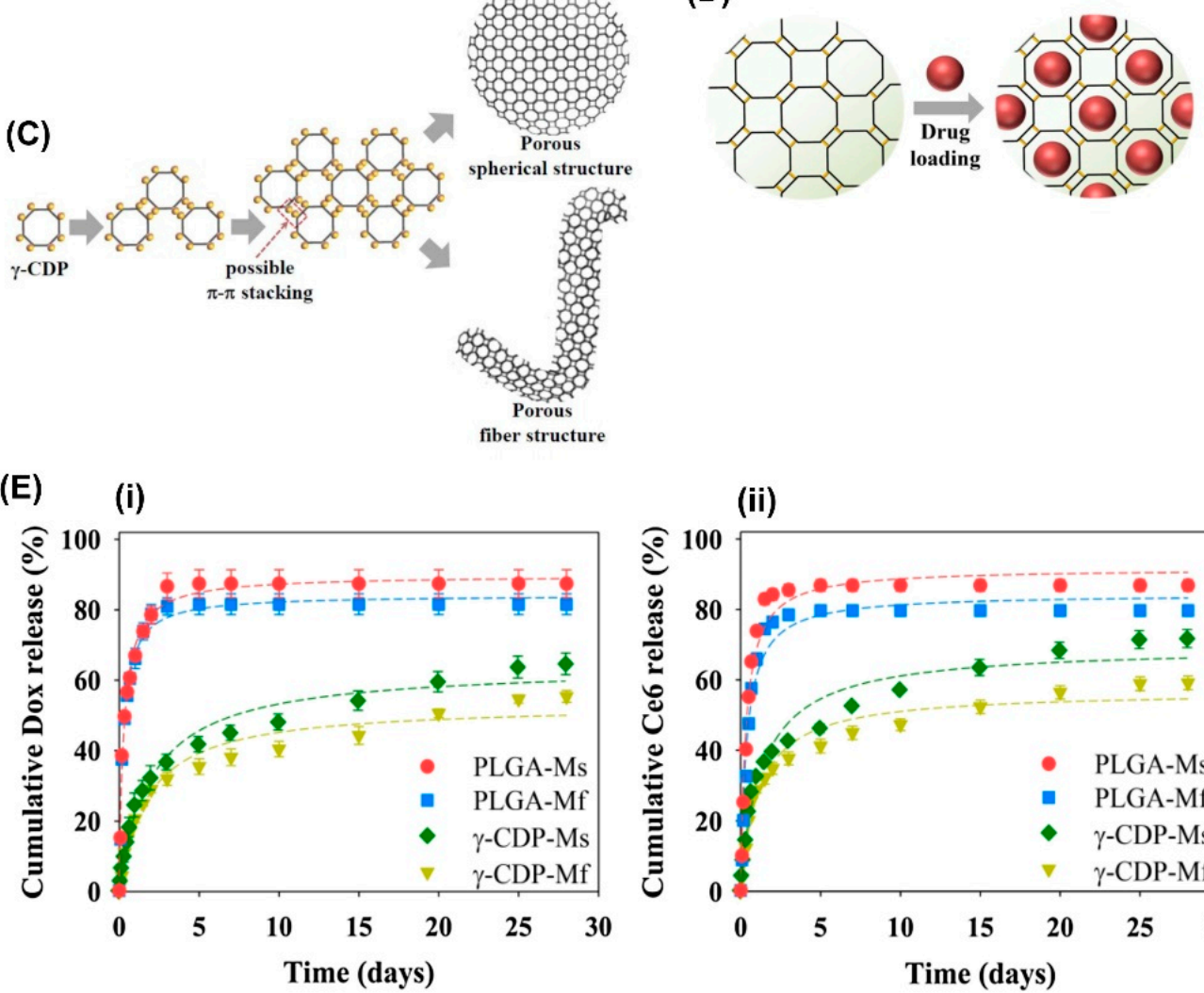

(ii)
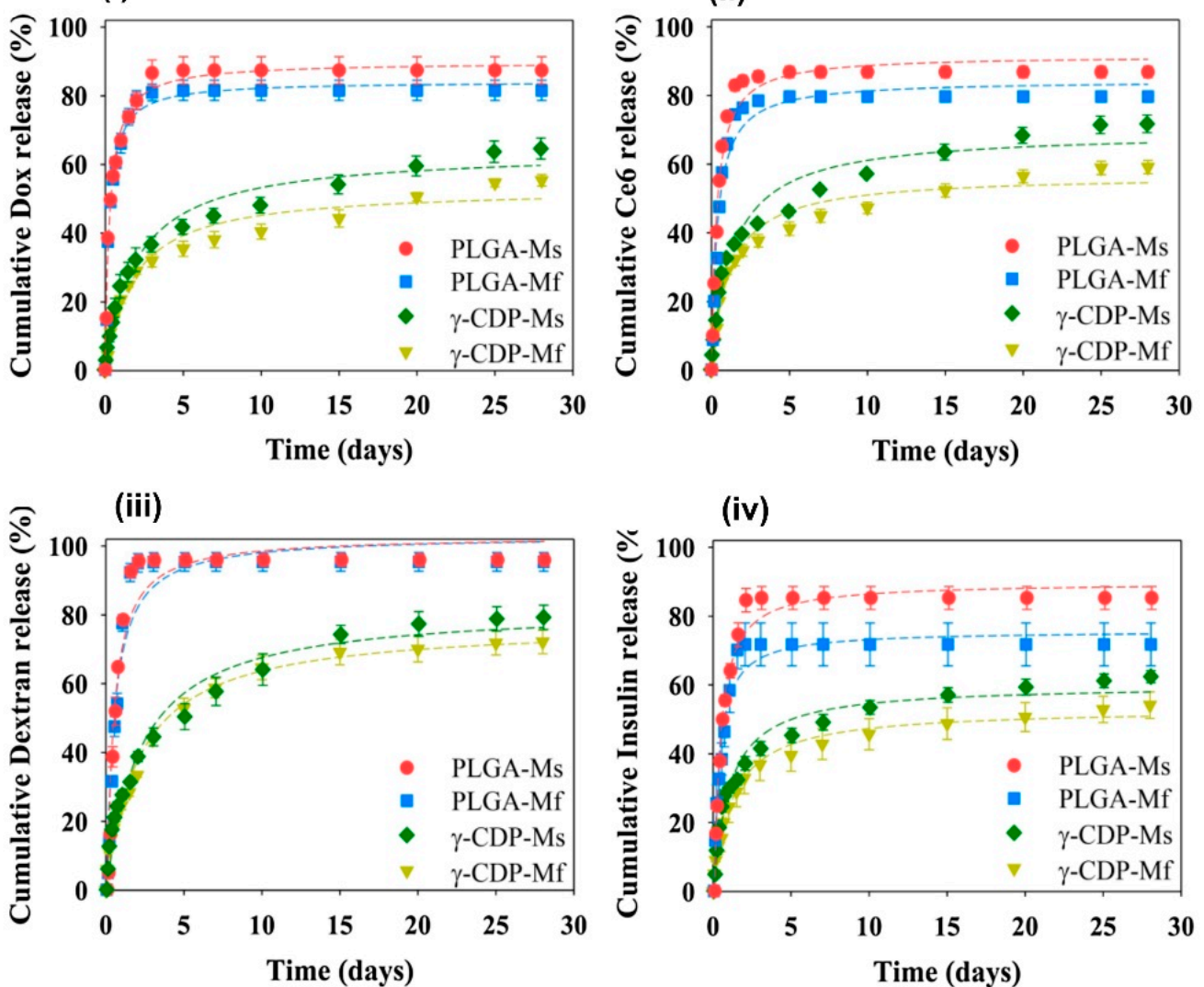

Figure 8. (A) A schematic representation of the electrospinning and electrospraying of $\gamma$-CyDPs. (B) The synthesis pathway of $\gamma$-CyDP. (C) Cartoon schemes of $\gamma$-CyDP-microspheres (Ms) or $\gamma$-CyDP microfibers (Mf) with porous structure and (D) their drug loading. (E) The cumulative molecule (i) Dox, (ii) Ce6, (iii) dextran, and (iv) insulin release (wt. \%) from PLGA-Ms, PLGA-Mf, $\gamma$-CyDP-Ms, and $\gamma$-CyDP-Mf $(n=3)$. The figure was reproduced from [182] with the permission of Elsevier, 2018. 
Table 3. Overview of polymer-free CyD/drug ICs electrospun nanofibers used in drug delivery.

\begin{tabular}{|c|c|c|c|}
\hline CyD type & Active molecule & Release data & Ref \\
\hline $\begin{array}{l}\mathrm{HP}-\beta-\mathrm{CyD} \\
\mathrm{HP}-\gamma-\mathrm{CyD}\end{array}$ & Triclosan & $\begin{array}{l}\text { Rapid release on contact with } \\
\text { water and significant } \\
\text { inhibition against } E \text {. coli and } S . \\
\text { aureus }\end{array}$ & [165] \\
\hline $\begin{array}{l}\mathrm{HP}-\beta-\mathrm{CyD} \\
\mathrm{HP}-\gamma-\mathrm{CyD}\end{array}$ & Camphor & $\begin{array}{c}\text { In gas phase, faster release at } \\
\text { higher temp., faster for the } \\
\text { HP- } \beta-C y D \text { system }\end{array}$ & [166] \\
\hline $\begin{array}{l}\mathrm{HP}-\beta-\mathrm{CyD}, \\
\mathrm{HP}-\gamma-\mathrm{CyD}, \\
\text { and } \mathrm{M}-\beta-\mathrm{CyD}\end{array}$ & Eugenol & $\begin{array}{l}\text { Rapid release on contact with } \\
\text { water, enhanced antioxidant } \\
\text { activity than eugenol itself }\end{array}$ & [167] \\
\hline $\begin{array}{l}\mathrm{HP}-\beta-\mathrm{CyD} \\
\mathrm{HP}-\gamma-\mathrm{CyD}\end{array}$ & Cineole and $p$-cymene & $\begin{array}{l}\text { Rapid release along with the } \\
\text { fiber dissolution }\end{array}$ & [168] \\
\hline $\begin{array}{l}\mathrm{HP}-\beta-\mathrm{CyD}, \\
\mathrm{HP}-\gamma-\mathrm{CyD}, \\
\text { and } \mathrm{M}-\beta-\mathrm{CyD}\end{array}$ & Linalool & $\begin{array}{l}\text { Rapid release, significant } \\
\text { inhibition against the growth } \\
\text { of E. coli and S. aureus }\end{array}$ & [169] \\
\hline $\begin{array}{l}\mathrm{HP}-\beta-\mathrm{CyD} \\
\mathrm{HP}-\gamma-\mathrm{CyD} \\
\text { and } \mathrm{M}-\beta-\mathrm{CyD}\end{array}$ & Limonene & $\begin{array}{c}25 \% \text { Release } \\
\text { M- } \beta-C y D / \text { limonene-IC-NF, } \\
51 \% \text { release } \\
\text { HP- } \beta-C y D / \text { limonene-IC-NF, } \\
88 \% \text { release } \\
\text { HP- } \gamma-C y D / \text { limonene-IC-NF } \\
\text { in } 100 \text { days }\end{array}$ & [170] \\
\hline $\begin{array}{l}\mathrm{HP}-\beta-\mathrm{CyD} \\
\mathrm{HP}-\gamma-\mathrm{CyD} \\
\text { and } \mathrm{M}-\beta-\mathrm{CyD}\end{array}$ & Geraniol & $\begin{array}{l}\text { Long-term stability of geraniol } \\
\text { in gas phase }\end{array}$ & [171] \\
\hline $\begin{array}{c}\mathrm{HP}-\beta-\mathrm{CyD} \\
\mathrm{HP}-\gamma-\mathrm{CyD} \\
\text { and } \mathrm{M}-\beta-\mathrm{CyD}\end{array}$ & Thymol & $\begin{array}{l}\text { Immediately on contact with } \\
\text { water }\end{array}$ & [172] \\
\hline $\begin{array}{l}\text { HP- } \beta-C y D, \\
\text { HP- } \gamma-C y D\end{array}$ & Menthol & $\begin{array}{l}\text { Rapid release along with the } \\
\text { fiber dissolution }\end{array}$ & [173] \\
\hline $\begin{array}{l}\mathrm{HP}-\beta-\mathrm{CyD} \\
\mathrm{HP}-\gamma-\mathrm{CyD} \\
\text { and } \mathrm{M}-\beta-\mathrm{CyD}\end{array}$ & Vanillin & $\begin{array}{c}\text { Immediately on contact with } \\
\text { water, enhanced antioxidant } \\
\text { activity with nanofibers }\end{array}$ & [174] \\
\hline $\mathrm{HP}-\beta-\mathrm{CyD}$ & Vitamin E & $\begin{array}{c}\text { Rapid and enhanced release, } \\
\text { higher antioxidant activity } \\
\text { with CyD }\end{array}$ & [175] \\
\hline $\begin{array}{l}\text { HP- } \beta-C y D, \\
\text { HP- } \beta-C y D\end{array}$ & Carvacrol & $\begin{array}{l}\text { Rapid release on contact with } \\
\text { water }\end{array}$ & [176] \\
\hline $\mathrm{SBE}_{7}-\beta-\mathrm{CyD}$ & Sulfisoxazole & $\begin{array}{l}\text { Rapid and enhanced release of } \\
\text { sulfisoxazole on contact with } \\
\text { water }\end{array}$ & [179] \\
\hline $\mathrm{HP}-\beta-\mathrm{CyD}$ & Diclofenac sodium & Release in few minutes & [180] \\
\hline $\mathrm{HP}-\beta-\mathrm{CyD}$ & Spironolactone & Total release in $1 \mathrm{~h}$ & [181] \\
\hline Phenylacetic- $\beta$-CyD & $\begin{array}{l}\text { Doxorubicin, fluorescein } \\
\text { isothiocyanate-dextran } \\
\text { (FITC-dextran), recombinant } \\
\text { human insulin (FITC-labeled } \\
\text { insulin) and chlorin e6 }\end{array}$ & $\begin{array}{c}50 \% \text { Release of drugs in vitro } \\
\text { in } 30 \text { days, } \sim 100 \% \text { release of } \\
\text { chlorin in vivo on day } 28\end{array}$ & [182] \\
\hline
\end{tabular}




\section{Concluding Remarks and Future Outlook}

Electrospinning has become a dynamic, rapidly changing field that can affect human lives in diverse ways. It allows for the production of electrospun nanofibers with tailored-made properties to address problems in the environment, biomedicine, textile, and food industries. High specific surface area, ease of operation, adaptability, tunable fiber texture, and a wide size spectrum make the electrospun nanofibers potential drug carriers with many intrinsic benefits, including enhanced drug loading, controlled release of drugs, and a short diffusion pathway. Further, processing parameters and structural modification allow tuning the fiber structure for the sustained release of drug molecules-for example, in the case of co-axial nanofibers with the drugs-embedded in the core. In this regard, various drug molecules with anticancer, antibiotic, antimicrobial, or antioxidant properties were incorporated into electrospun fibers, mostly using their ICs with CyD. The non-specific incorporation of such drug molecules can cause undesired release profiles, low drug loadings, activity loss of environmentally sensitive drugs, or other problems. In this regard, the incorporation of biocompatible nanocarriers into such systems allows the fabrication of high-performance drug delivery nanomaterials. Toward this goal, CyD molecules have found a large application area because of their unique 3D structure, which endows nanofibers with distinct features e.g., enhanced drug solubility, stability, and bioavailability useful in drug delivery applications. Furthermore, they do not provoke the immune system and have low toxicities to mammals. Hence, they have become important excipients in pharmaceutical applications. Native $\mathrm{CyD}$, particularly $\beta-\mathrm{CyD}$, have ideal cavity size related to complex with a wide range of chemicals but have significant issues related to the poor water solubility of native CyD. These drawbacks of $\beta-C y D$ can be mitigated by chemical modifications to produce highly soluble derivatives, such as hydroxypropyl functional-CyD. CyD-functional electrospun nanofibers were prepared by either blending of CyD-drug complexes with polymers or using CyD polymers with another polymer carrier or standalone. CyD molecules could also be electrospun without the requirement of a carrier polymer. In the latter case, $\mathrm{CyD}$ and guest molecules were mixed to form ICs and their electrospinning produced polymer-free nanofibers with high drug loading. However, these fibers, on contact, rapidly dissolve in water and release the entrapped drug molecules in the form of CyD-drug ICs without any control on drug release. Tables 1-3 give the characteristics of some selected examples on CyD functional electrospun nanofibers used in drug delivery applications. All these fiber systems have their own pros and cons. Still, there is a growing interest to engineer CyD-functional drug delivery systems that deliver therapeutics in a safe, effective, and targeted fashion. The most of researches in this field concentrated on the blending of CyD-drug ICs with various polymers. This route produces CyD-drug IC loaded polymeric nanofibers with longer dissolution time depending on the structural properties of polymeric carrier in the fiber. The CyD-drug ICs can also be electrospun in the absence of a polymer. However, such fibers rapidly dissolve on contact with water, and drug molecules are released in the forms of CyD-drug ICs. In contrast to both methods, the polyCyD fibers can be engineered and used in drug delivery with a better control on release profiles. A schematic overview of the CyD-functional nanofibers was shown in Figure 9, where important parameters of the relevant synthesis routes are pointed out. Each preparation approach comprises different benefits. While polymer-free $\mathrm{CyD}$ nanofibers are simpler to produce, they suffer from the instant water solubility. However, in this context, hydrophobically-modified CyD can offer water-insoluble polymer-free fiber meshes. On the other hand, polyCyD functional nanofibers have certain difficulties in the synthesis of functional CyD derivatives and their polymers. Regardless of preparation route, the ability to tune fiber structure should facilitate the sustained release of drugs, such as through co-axial electrospinning.

The use of $\mathrm{CyD}$ in electrospun nanofibers for drug delivery systems are likely to find increasing interest in the coming years. Currently, there are significant advances in polyCyD electrospun nanofibers produced without the need of any additional polymeric carrier. These water insoluble nanofibers exhibited the efficient removal of water micropollutants, e.g., methylene blue, because of their high active CyD contents [183]. In the future, such nanofibers may find applications in drug delivery. Further, a stimulus can be applied for the release of drug molecules from the CyD cavity in a 
controllable fashion. Likewise, CyD-containing polymers, particularly those contain CyD as pendent motifs on the polymer backbone can offer promising results for the sustained release of drugs from the fiber matrix depending on the hydrophobicity of the polymer. In this regard, cross-linked nano-porous $\beta$-CyD polymers showed enhanced IC constant as high as $10^{9} \mathrm{M}^{-1}$ than those uncross-linked ones (native $\beta-C y D, 10^{3} \mathrm{M}^{-1}$ ) [184]. Beside their use in in vitro drug release applications, CyD-functional electrospun materials will find more applications as implant materials in tissue engineering. Unlike CyD-free electrospun fibers, the functionalization of electrospun fibers with CyD can improve their properties in terms of high drug loading, increased stability, and bioavailability of the payloads in the body.

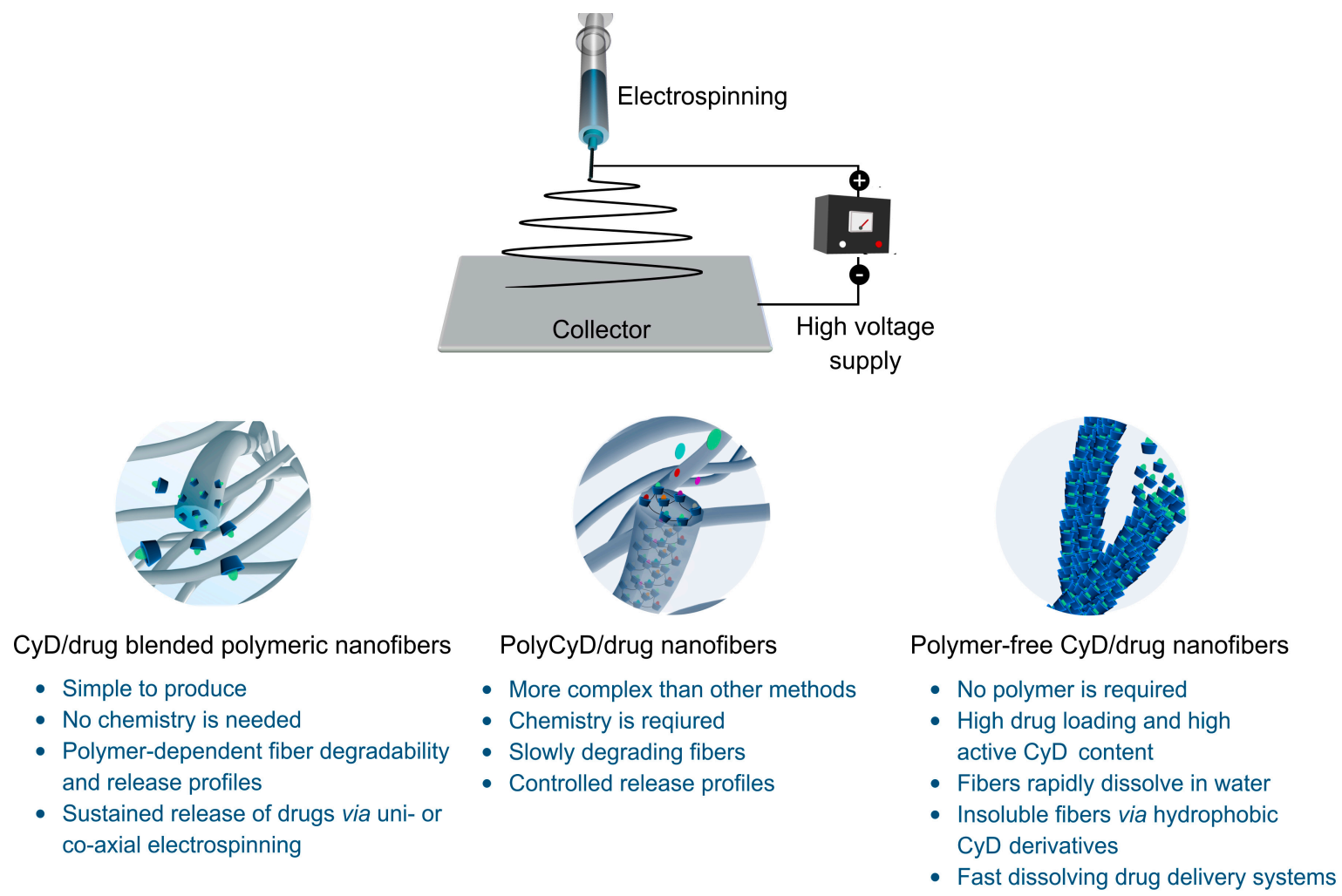

Figure 9. Cartoon illustration of CyD-functional electrospun nanofibers used for drug delivery applications.

To conclude, drug delivery is a dynamic and complex process and can be adapted to meet the needs of the targeted application. Advanced drug delivery therapy requires nontoxic pharmaceutical excipients to provide high drug loading and keeps the drugs stable, active, and accessible for bioavailability. In this regard, CyD-functional nanofibers would be one of the best material systems for drug delivery applications since they offer intrinsic features of both electrospun nanofibers and CyD possessing a hydrophobic molecular-environment for drug entrapment. CyD, thus, significantly increase water solubility of hydrophobic drug molecules (i.e., for high drug loading) and shield drug molecules from physiological degradation or elimination for bioavailability while nanofiber form offers high specific surface area, ease of operation, and further control on the nanofiber form for the sustained release of the entrapped drug molecules. As the electrospinning produces tailored nanostructured materials with further control mechanisms on drug release, the utilization of CyD-functional electrospun materials will increase to meet the demands of advanced drug delivery systems.

Author Contributions: F.T. and T.U. conceived the review. F.T. with the supervision of T.U. analyzed the references and wrote the manuscript. T.U. revised and reviewed the manuscript. 
Conflicts of Interest: The authors have no conflicts of interest to declare.

\section{Abbreviations}

\begin{tabular}{|c|c|}
\hline Ac- $\beta-C y D P$ & Peracetyl- $\beta-C y D$ polymer \\
\hline AITC & Allyl isocyanate \\
\hline AV & Aloe Vera \\
\hline $\mathrm{CEO}$ & Cinnamon essential oil \\
\hline CIP & Ciprofloxacin \\
\hline CUR & Curcumin \\
\hline CyD & Cyclodextrins \\
\hline $\mathrm{CZ}$ & Clotrimazole \\
\hline DDS & Drug Delivery System \\
\hline DPPH & 2,2-Diphenyl-1-picrylhydrazyl \\
\hline E. coli & Escherichia coli \\
\hline EEO & Eucalyptus essential oil \\
\hline $\mathrm{EtOH}$ & Ethanol \\
\hline FDA & Federal Drug Administration \\
\hline GC-MS & Gas chromatograph mass spectrometry \\
\hline HCPT & Hydroxycamptothecin \\
\hline HPC & Hydroxypropyl cellulose \\
\hline $\mathrm{HP}-\beta-\mathrm{CyD}$ & Hydroxypropyl- $\beta$-cyclodextrin \\
\hline IC & Inclusion-Complex \\
\hline $\mathrm{MX}$ & Meloxicam \\
\hline M- $\beta-C y D$ & Methyl- $\beta$-Cyclodextrin \\
\hline NAP & Naproxen \\
\hline PCL & Polycaprolactone \\
\hline PEG & Poly(ethylene glycol) \\
\hline PEO & Poly(ethylene oxide) \\
\hline PLACL & Poly (L-lactic acid-co-e-caprolactone) \\
\hline PLLA & Poly (L-lactic acid) \\
\hline PMAA & Poly(methylacrylic acid) \\
\hline PolyCyD & Polycyclodextrin \\
\hline PROP & Propranolol hydrochloride \\
\hline PS & Polystyrene \\
\hline PVA & Poly(vinyl alcohol) \\
\hline RA & Retinyl acetate \\
\hline RH & Relative humidity \\
\hline S. aureus & Staphylococcus aureus \\
\hline SA & Salicylic acid \\
\hline SAg & Silver sulfadiazine \\
\hline SFS & Sulfisoxazole \\
\hline TAM & Tamoxifen \\
\hline $\mathrm{TCN}$ & Tetracycline \\
\hline VRC & Voriconazole \\
\hline
\end{tabular}

\section{References}

1. Zeng, J.; Xu, X.; Chen, X.; Liang, Q.; Bian, X.; Yang, L.; Jing, X. Biodegradable electrospun fibers for drug delivery. J. Control. Release 2003, 92, 227-231. [CrossRef]

2. Sill, T.J.; von Recum, H.A. Electrospinning: Applications in drug delivery and tissue engineering. Biomaterials 2008, 29, 1989-2006. [CrossRef] [PubMed]

3. Yoo, H.S.; Kim, T.G.; Park, T.G. Surface-functionalized electrospun nanofibers for tissue engineering and drug delivery. Adv. Drug Deliv. Rev. 2009, 61, 1033-1042. [CrossRef] [PubMed] 
4. Kenawy, E.-R.; Bowlin, G.L.; Mansfield, K.; Layman, J.; Simpson, D.G.; Sanders, E.H.; Wnek, G.E. Release of tetracycline hydrochloride from electrospun poly(ethylene-co-vinylacetate), poly(lactic acid), and a blend. J. Control. Release 2002, 81, 57-64. [CrossRef]

5. Zeng, J.; Yang, L.; Liang, Q.; Zhang, X.; Guan, H.; Xu, X.; Chen, X.; Jing, X. Influence of the drug compatibility with polymer solution on the release kinetics of electrospun fiber formulation. J. Control. Release 2005, 105, 43-51. [CrossRef] [PubMed]

6. Katti, D.S.; Robinson, K.W.; Ko, F.K.; Laurencin, C.T. Bioresorbable nanofiber-based systems for wound healing and drug delivery: Optimization of fabrication parameters. J. Biomed. Mater. Res. Part B Appl. Biomater. 2004, 70B, 286-296. [CrossRef] [PubMed]

7. Wenguo, C.; Yue, Z.; Jiang, C. Electrospun nanofibrous materials for tissue engineering and drug delivery. Sci. Technol. Adv. Mater. 2010, 11, 014108.

8. $\quad$ Deng-Guang, Y.; Xia-Xia, S.; Chris, B.-W.; Kenneth, W.; Li-Min, Z.; Bligh, S.W.A. Oral fast-dissolving drug delivery membranes prepared from electrospun polyvinylpyrrolidone ultrafine fibers. Nanotechnology 2009, 20, 055104.

9. Bognitzki, M.; Czado, W.; Frese, T.; Schaper, A.; Hellwig, M.; Steinhart, M.; Greiner, A.; Wendorff, J.H. Nanostructured fibers via electrospinning. Adv. Mater. 2001, 13, 70-72. [CrossRef]

10. He, C.L.; Huang, Z.M.; Han, X.J.; Liu, L.; Zhang, H.S.; Chen, L.S. Coaxial electrospun poly(L-lactic acid) ultrafine fibers for sustained drug delivery. J. Macromol. Sci. Part B 2006, 45, 515-524. [CrossRef]

11. Uyar, T.; Kny, E. Electrospun Materials for Tissue Engineering and Biomedical Applications: Research, Design and Commercialization; Elsevier: New York, NY, USA; Woodhead Publishing: Sawston/Cambridge, UK, 2017; ISBN 9780081010228.

12. Grafahrend, D.; Heffels, K.-H.; Beer, M.V.; Gasteier, P.; Möller, M.; Boehm, G.; Dalton, P.D.; Groll, J. Degradable polyester scaffolds with controlled surface chemistry combining minimal protein adsorption with specific bioactivation. Nat. Mater. 2010, 10, 67. [CrossRef] [PubMed]

13. Choi Ji, S.; Messersmith Phillip, B.; Yoo Hyuk, S. Decoration of electrospun nanofibers with monomeric catechols to facilitate cell adhesion. Macromol. Biosci. 2013, 14, 270-279. [CrossRef] [PubMed]

14. Pires, L.R. 9-electrospun fibers for drug and molecular delivery a2-guarino, vincenzo. In Electrofluidodynamic Technologies (Efdts) for Biomaterials and Medical Devices; Ambrosio, L., Ed.; Woodhead Publishing: Sawston/Cambridge, UK, 2018; pp. 157-177.

15. Yu, D.-G.; Li, X.-Y.; Wang, X.; Chian, W.; Liao, Y.-Z.; Li, Y. Zero-order drug release cellulose acetate nanofibers prepared using coaxial electrospinning. Cellulose 2013, 20, 379-389. [CrossRef]

16. Gizaw, M.; Thompson, J.; Faglie, A.; Lee, S.-Y.; Neuenschwander, P.; Chou, S.-F. Electrospun fibers as a dressing material for drug and biological agent delivery in wound healing applications. Bioengineering 2018, 5, 9. [CrossRef] [PubMed]

17. Liu, M.; Duan, X.-P.; Li, Y.-M.; Yang, D.-P.; Long, Y.-Z. Electrospun nanofibers for wound healing. Mater. Sci. Eng. C 2017, 76, 1413-1423. [CrossRef] [PubMed]

18. Pinho, E.; Grootveld, M.; Soares, G.; Henriques, M. Cyclodextrin-based hydrogels toward improved wound dressings. Crit. Rev. Biotechnol. 2014, 34, 328-337. [CrossRef] [PubMed]

19. Luo, X.; Xie, C.; Wang, H.; Liu, C.; Yan, S.; Li, X. Antitumor activities of emulsion electrospun fibers with core loading of hydroxycamptothecin via intratumoral implantation. Int. J. Pharm. 2012, 425, 19-28. [CrossRef] [PubMed]

20. Deluzio, T.G.B.; Penev, K.I.; Mequanint, K. Cyclodextrin inclusion complexes as potential oxygen delivery vehicles in tissue engineering. J. Biomater. Tissue Eng. 2014, 4, 957-966. [CrossRef]

21. Khajavi, R.; Abbasipour, M. Electrospinning as a versatile method for fabricating coreshell, hollow and porous nanofibers. Sci. Iran. 2012, 19, 2029-2034. [CrossRef]

22. Al-Enizi, A.; Zagho, M.; Elzatahry, A. Polymer-based electrospun nanofibers for biomedical applications. Nanomaterials 2018, 8, 259. [CrossRef]

23. Dash, T.K.; Konkimalla, V.B. Poly-e-caprolactone based formulations for drug delivery and tissue engineering: A review. J. Control. Release 2012, 158, 15-33. [CrossRef]

24. Yoon, H.; Kim, G. A three-dimensional polycaprolactone scaffold combined with a drug delivery system consisting of electrospun nanofibers. J. Pharm. Sci. 2011, 100, 424-430. [CrossRef]

25. Chen, S.C.; Huang, X.B.; Cai, X.M.; Lu, J.; Yuan, J.; Shen, J. The influence of fiber diameter of electrospun poly(lactic acid) on drug delivery. Fibers Polym. 2012, 13, 1120-1125. [CrossRef] 
26. Repanas, A.; Glasmacher, B. Dipyridamole embedded in polycaprolactone fibers prepared by coaxial electrospinning as a novel drug delivery system. J. Drug Deliv. Sci. Technol. 2015, 29, 132-142. [CrossRef]

27. Schaub, N.J.; Le Beux, C.; Miao, J.; Linhardt, R.J.; Alauzun, J.G.; Laurencin, D.; Gilbert, R.J. The effect of surface modification of aligned poly-L-lactic acid electrospun fibers on fiber degradation and neurite extension. PLoS ONE 2015, 10, e0136780. [CrossRef] [PubMed]

28. Chou, S.-F.; Carson, D.; Woodrow, K.A. Current strategies for sustaining drug release from electrospun nanofibers. J. Control. Release 2015, 220, 584-591. [CrossRef]

29. Ulery, B.D.; Nair, L.S.; Laurencin, C.T. Biomedical applications of biodegradable polymers. J. Polym. Sci. Part B Polym. Phys. 2011, 49, 832-864. [CrossRef]

30. Otero-Espinar, F.J.; Torres-Labandeira, J.J.; Alvarez-Lorenzo, C.; Blanco-Méndez, J. Cyclodextrins in drug delivery systems. J. Drug Deliv. Sci. Technol. 2010, 20, 289-301. [CrossRef]

31. Loftsson, T.; Vogensen, S.B.; Brewster, M.E.; Konradsdottir, F. Effects of cyclodextrins on drug delivery through biological membranes. J. Pharm. Sci. 2007, 96, 2532-2546. [CrossRef]

32. Garg, K.; Bowlin, G.L. Electrospinning jets and nanofibrous structures. Biomicrofluidics 2011, 5, 013403. [CrossRef]

33. Darrell, H.R.; Iksoo, C. Nanometre diameter fibres of polymer, produced by electrospinning. Nanotechnology 1996, 7, 216.

34. Ziabicki, A. Fundamentals of Fibre Formation; Wiley-Interscience: New York, NY, USA, 1976.

35. Fong, H.; Chun, I.; Reneker, D.H. Beaded nanofibers formed during electrospinning. Polymer 1999, 40, 4585-4592. [CrossRef]

36. Lee, K.H.; Kim, H.Y.; Bang, H.J.; Jung, Y.H.; Lee, S.G. The change of bead morphology formed on electrospun polystyrene fibers. Polymer 2003, 44, 4029-4034. [CrossRef]

37. Uyar, T.; Besenbacher, F. Electrospinning of uniform polystyrene fibers: The effect of solvent conductivity. Polymer 2008, 49, 5336-5343. [CrossRef]

38. Li, Z.; Wang, C. Effects of working parameters on electrospinning. In One-Dimensional Nanostructures: Electrospinning Technique and Unique Nanofibers; Li, Z., Wang, C., Eds.; Springer: Berlin/Heidelberg, Germany, 2013; pp. 15-28.

39. Qin, X.H.; Yang, E.L.; Li, N.; Wang, S.Y. Effect of different salts on electrospinning of polyacrylonitrile (PAN) polymer solution. J. Appl. Polym. Sci. 2006, 103, 3865-3870. [CrossRef]

40. Loftsson, T.; Duchene, D. Cyclodextrins and their pharmaceutical applications. Int. J. Pharm. 2007, 329, 1-11. [CrossRef]

41. Crini, G. Review: A history of cyclodextrins. Chem. Rev. 2014, 114, 10940-10975. [CrossRef]

42. Morillo, E.; Sánchez-Trujillo, M.A.; Moyano, J.R.; Villaverde, J.; Gómez-Pantoja, M.E.; Pérez-Martínez, J.I. Enhanced solubilisation of six pahs by three synthetic cyclodextrins for remediation applications: Molecular modelling of the inclusion complexes. PLoS ONE 2012, 7, e44137. [CrossRef]

43. Song, L.X.; Bai, L.; Xu, X.M.; He, J.; Pan, S.Z. Inclusion complexation, encapsulation interaction and inclusion number in cyclodextrin chemistry. Coord. Chem. Rev. 2009, 253, 1276-1284. [CrossRef]

44. Villiers, A. Sur la fermentation de la fecule par l'action du ferment butyrique. Compt. Rend. Acad. Sci. 1891, 112, 536-538.

45. Lakkakula, J.R.; Krause, R.W.M. A vision for cyclodextrin nanoparticles in drug delivery systems and pharmaceutical applications. Nanomedicine 2014, 9, 877-894. [CrossRef] [PubMed]

46. Tiwari, G.; Tiwari, R.; Rai, A.K. Cyclodextrins in delivery systems: Applications. J. Pharm. Bioallied Sci. 2010, 2, 72-79. [CrossRef] [PubMed]

47. Shieh, W.J.; Hedges, A.R. Properties and applications of cyclodextrins. J. Macromol. Sci. Part A 1996, 33, 673-683. [CrossRef]

48. Singh, M.; Sharma, R.; Banerjee, U.C. Biotechnological applications of cyclodextrins. Biotechnol. Adv. 2002, 20, 341-359. [CrossRef]

49. Szejtli, J. Introduction and general overview of cyclodextrin chemistry. Chem. Rev. 1998, 98, 1743-1754. [CrossRef] [PubMed]

50. Davis, M.E.; Brewster, M.E. Cyclodextrin-based pharmaceutics: Past, present and future. Nat. Rev. Drug Discov. 2004, 3, 1023. [CrossRef] 
51. Wolfram, S.; Mathias, N. Topographie der cyclodextrin-einschlußverbindungen, VII. Röntgenstrukturanalyse des $\alpha$-cyclodextrin. Krypton-pentahydrats. Zum einschlußmechanismus des modell-enzyms. Chem. Ber. 1976, 109, 503-517.

52. Harata, K. Structural aspects of stereodifferentiation in the solid state. Chem. Rev. 1998, 98, $1803-1828$. [CrossRef]

53. Sonoda, Y.; Hirayama, F.; Arima, H.; Yamaguchi, Y.; Saenger, W.; Uekama, K. Cyclodextrin-based isolation of ostwald's metastable polymorphs occurring during crystallization. Chem. Commun. 2006, 517-519. [CrossRef] [PubMed]

54. Hapiot, F.; Tilloy, S.; Monflier, E. Cyclodextrins as supramolecular hosts for organometallic complexes. Chem. Rev. 2006, 106, 767-781. [CrossRef] [PubMed]

55. Loftsson, T.; Jarho, P.; Másson, M.; Järvinen, T. Cyclodextrins in drug delivery. Expert Opin. Drug Deliv. 2005, 2, 335-351. [CrossRef] [PubMed]

56. Uekama, K.; Hirayama, F.; Irie, T. Cyclodextrin drug carrier systems. Chem. Rev. 1998, 98, $2045-2076$. [CrossRef] [PubMed]

57. Frank, D.W.; Gray, J.E.; Weaver, R.N. Cyclodextrin nephrosis in the rat. Am. J. Pathol. 1976, 83, 367-382. [PubMed]

58. Matsuda, K.; Mera, Y.; Segawa, Y. Acute toxicity study of $\gamma$-cyclodextrin $(\gamma-C D)$ in mice and rats. Pharmacometrics 1983, 26, 287-291.

59. Irie, T.; Uekama, K. Pharmaceutical applications of cyclodextrins. Iii. Toxicological issues and safety evaluation. J. Pharm. Sci. 1997, 86, 147-162. [CrossRef]

60. Ohtani, Y.; Irie, T.; Uekama, K.; Fukunaga, K.; Pitha, J. Differential effects of $\alpha$-, $\beta$ - and $\gamma$-cyclodextrins on human erythrocytes. Eur. J. Biochem. 1989, 186, 17-22. [CrossRef]

61. Zimmer, S.; Grebe, A.; Bakke, S.S.; Bode, N.; Halvorsen, B.; Ulas, T.; Skjelland, M.; De Nardo, D.; Labzin, L.I.; Kerksiek, A.; et al. Cyclodextrin promotes atherosclerosis regression via macrophage reprogramming. Sci. Transl. Med. 2016, 8, 333ra350. [CrossRef]

62. Rajewski, R.A.; Traiger, G.; Bresnahan, J.; Jaberaboansar, P.; Stella, V.J.; Thompson, D.O. Preliminary safety evaluation of parenterally administered sulfoalkyl ether $\beta$-cyclodextrin derivatives. J. Pharm. Sci. 1995, 84, 927-932. [CrossRef]

63. Kantner, I.; Erben, R.G. Long-term parenteral administration of 2-hydroxypropyl- $\beta$-cyclodextrin causes bone loss. Toxicol. Pathol. 2012, 40, 742-750. [CrossRef]

64. Szente, L.; Szejtli, J. Cyclodextrins as food ingredients. Trends Food Sci. Technol. 2004, 15, 137-142. [CrossRef]

65. Stella, V.J.; He, Q. Cyclodextrins. Toxicol. Pathol. 2008, 36, 30-42. [CrossRef] [PubMed]

66. Frömming, K.-H.; Szejtli, J. Pharmacokinetics and toxicology of cyclodextrins. In Cyclodextrins in Pharmacy; Frömming, K.-H., Szejtli, J., Eds.; Springer: Dordrecht, The Netherlands, 1994; pp. 33-44.

67. Miranda, J.C.D.; Martins, T.E.A.; Veiga, F.; Ferraz, H.G. Cyclodextrins and ternary complexes: Technology to improve solubility of poorly soluble drugs. Braz. J. Pharm. Sci. 2011, 47, 665-681. [CrossRef]

68. Amiri, S. Introduction. In Cyclodextrins: Properties and Industrial Applications; Amiri, S., Ed.; Wiley: Hoboken, NY, USA, 2017; Volume 1, pp. 1-39.

69. Mohanty, J.; Bhasikuttan, A.C.; Nau, W.M.; Pal, H. Host-guest complexation of neutral red with macrocyclic host molecules: Contrasting pka shifts and binding affinities for cucurbit[7]uril and $\beta$-cyclodextrin. J. Phys. Chem. B 2006, 110, 5132-5138. [CrossRef] [PubMed]

70. Kim, H.; Jeong, K.; Park, H.; Jung, S. Preference prediction for the stable inclusion complexes between cyclodextrins and monocyclic insoluble chemicals based on monte carlo docking simulations. J. Incl. Phenom. Macrocycl. Chem. 2006, 54, 165-170. [CrossRef]

71. Li, S.; Purdy, W.C. Cyclodextrins and their applications in analytical chemistry. Chem. Rev. 1992, 92, 1457-1470. [CrossRef]

72. Al Omari, M.M.; Zughul, M.B.; Davies, J.E.D.; Badwan, A.A. Effect of buffer species on the complexation of basic drug terfenadine with $\beta$-cyclodextrin. J. Incl. Phenom. Macrocycl. Chem. 2007, 58, 227-235. [CrossRef]

73. Rekharsky, M.V.; Inoue, Y. Complexation thermodynamics of cyclodextrins. Chem. Rev. 1998, 98, 1875-1918. [CrossRef]

74. Dua, K.; Pabreja, K.; Ramana, M.V.; Lather, V. Dissolution behavior of $\beta$-cyclodextrin molecular inclusion complexes of aceclofenac. J. Pharm. Bioallied Sci. 2011, 3, 417-425. [CrossRef] 
75. Shin, K.-M.; Dong, T.; He, Y.; Taguchi, Y.; Oishi, A.; Nishida, H.; Inoue, Y. Inclusion complex formation between $\alpha$-cyclodextrin and biodegradable aliphatic polyesters. Macromol. Biosci. 2004, 4, 1075-1083. [CrossRef]

76. Oster, M.; Schlatter, G.; Gallet, S.; Baati, R.; Pollet, E.; Gaillard, C.; Averous, L.; Fajolles, C.; Hebraud, A. The study of the pseudo-polyrotaxane architecture as a route for mild surface functionalization by click chemistry of poly( $\varepsilon$-caprolactone)-based electrospun fibers. J. Mater. Chem. B 2017, 5, 2181-2189. [CrossRef]

77. Rusa, C.C.; Wei, M.; Bullions, T.A.; Rusa, M.; Gomez, M.A.; Porbeni, F.E.; Wang, X.; Shin, I.D.; Balik, C.M.; White, J.L.; et al. Controlling the polymorphic behaviors of semicrystalline polymers with cyclodextrins. Cryst. Growth Design 2004, 4, 1431-1441. [CrossRef]

78. Topuz, F.; Uyar, T. Cyclodextrin-functionalized mesostructured silica nanoparticles for removal of polycyclic aromatic hydrocarbons. J. Colloid Interface Sci. 2017, 497, 233-241. [CrossRef] [PubMed]

79. Topuz, F.; Uyar, T. Poly-cyclodextrin cryogels with aligned porous structure for removal of polycyclic aromatic hydrocarbons (PAHS) from water. J. Hazard. Mater. 2017, 335, 108-116. [CrossRef] [PubMed]

80. Kotronia, M.; Kavetsou, E.; Loupassaki, S.; Kikionis, S.; Vouyiouka, S.; Detsi, A. Encapsulation of oregano (Origanum onites L.) essential oil in $\beta$-cyclodextrin $(\beta-C D)$ : Synthesis and characterization of the inclusion complexes. Bioengineering 2017, 4, 74. [CrossRef] [PubMed]

81. Wadhwa, G.; Kumar, S.; Chhabra, L.; Mahant, S.; Rao, R. Essential coil-cyclodextrin complexes: An updated review. J. Incl. Phenom. Macrocycl. Chem. 2017, 89, 39-58. [CrossRef]

82. Zelikin, A.N.; Ehrhardt, C.; Healy, A.M. Materials and methods for delivery of biological drugs. Nat. Chem. 2016, 8, 997. [CrossRef] [PubMed]

83. Celebioglu, A.; Uyar, T. Electrospinning of nanofibers from non-polymeric systems: Electrospun nanofibers from native cyclodextrins. J. Colloid Interface Sci. 2013, 404, 1-7. [CrossRef] [PubMed]

84. Uyar, T.; El-Shafei, A.; Wang, X.; Hacaloglu, J.; Tonelli, A.E. The solid channel structure inclusion complex formed between guest styrene and host $\gamma$-cyclodextrin. J. Incl. Phenom. Macrocycl. Chem. 2006, 55, 109-121. [CrossRef]

85. Kayaci, F.; Ertas, Y.; Uyar, T. Enhanced thermal stability of eugenol by cyclodextrin inclusion complex encapsulated in electrospun polymeric nanofibers. J. Agric. Food Chem. 2013, 61, 8156-8165. [CrossRef]

86. Kayaci, F.; Sen, H.S.; Durgun, E.; Uyar, T. Functional electrospun polymeric nanofibers incorporating geraniol-cyclodextrin inclusion complexes: High thermal stability and enhanced durability of geraniol. Food Res. Int. 2014, 62, 424-431. [CrossRef]

87. Liu, L.; Guo, Q.-X. The driving forces in the inclusion complexation of cyclodextrins. J. Incl. Phenom. Macrocycl. Chem. 2002, 42, 1-14. [CrossRef]

88. Canbolat, M.F.; Celebioglu, A.; Uyar, T. Drug delivery system based on cyclodextrin-naproxen inclusion complex incorporated in electrospun polycaprolactone nanofibers. Colloids Surf. B Biointerfaces 2014, 115, 15-21. [CrossRef] [PubMed]

89. Sadlej-Sosnowska, N.; Kozerski, L.; Bednarek, E.; Sitkowski, J. Fluorometric and NMR studies of the naproxen-cyclodextrin inclusion complexes in aqueous solutions. J. Incl. Phenom. Macrocycl. Chem. 2000, 37, 383-394. [CrossRef]

90. Banik, A.; Gogoi, P.; Saikia, M.D. Interaction of naproxen with $\beta$-cyclodextrin and its derivatives/polymer: Experimental and molecular modeling studies. J. Incl. Phenom. Macrocycl. Chem. 2012, 72, 449-458. [CrossRef]

91. Akduman, C.; Ozguney, I.; Kumbasar, E.P. Electrospun thermoplastic polyurethane mats containing naproxen-cyclodextrin inclusion complex. Autex Res. J. 2014, 14, 239-246. [CrossRef]

92. Aytac, Z.; Sen, H.S.; Durgun, E.; Uyar, T. Sulfisoxazole/cyclodextrin inclusion complex incorporated in electrospun hydroxypropyl cellulose nanofibers as drug delivery system. Colloids Surf. B. Biointerfaces 2015, 128, 331-338. [CrossRef]

93. Connor, E.E. Sulfonamide antibiotics. Prim. Care Update Ob Gyns 1998, 5, 32-35. [CrossRef]

94. Tonglairoum, P.; Ngawhirunpat, T.; Rojanarata, T.; Panomsuk, S.; Kaomongkolgit, R.; Opanasopit, P. Fabrication of mucoadhesive chitosan coated polyvinylpyrrolidone/cyclodextrin/clotrimazole sandwich patches for oral candidiasis. Carbohydr. Polym. 2015, 132, 173-179. [CrossRef]

95. Sun, X.; Yu, Z.; Cai, Z.; Yu, L.; Lv, Y. Voriconazole composited polyvinyl alcohol/hydroxypropyl- $\beta$-cyclodextrin nanofibers for ophthalmic delivery. PLoS ONE 2016, 11, e0167961. [CrossRef] 
96. Siafaka, P.I.; Okur, N.U.; Mone, M.; Giannakopoulou, S.; Er, S.; Pavlidou, E.; Karavas, E.; Bikiaris, D.N. Two different approaches for oral administration of voriconazole loaded formulations: Electrospun fibers versus $\beta$-cyclodextrin complexes. Int. J. Mol. Sci. 2016, 17, 282. [CrossRef]

97. Samprasit, W.; Akkaramongkolporn, P.; Ngawhirunpat, T.; Rojanarata, T.; Kaomongkolgit, R.; Opanasopit, P. Fast releasing oral electrospun PVP/CD nanofiber mats of taste-masked meloxicam. Int. J. Pharm. 2015, 487, 213-222. [CrossRef]

98. Noble, S.; Balfour, J.A. Meloxicam. Drugs 1996, 51, 424-430. [CrossRef] [PubMed]

99. Samprasit, W.; Akkaramongkolporn, P.; Kaomongkolgit, R.; Opanasopit, P. Cyclodextrin-based oral dissolving films formulation of taste-masked meloxicam. Pharm. Dev. Technol. 2018, 23, 530-539. [CrossRef]

100. Monteiro, A.P.F.; Rocha, C.M.S.L.; Oliveira, M.F.; Gontijo, S.M.L.; Agudelo, R.R.; Sinisterra, R.D.; Cortés, M.E. Nanofibers containing tetracycline/ $\beta$-cyclodextrin: Physico-chemical characterization and antimicrobial evaluation. Carbohydr. Polym. 2017, 156, 417-426. [CrossRef] [PubMed]

101. Prakasam, A.; Elavarasu, S.S.; Natarajan, R.K. Antibiotics in the management of aggressive periodontitis. J. Pharm. Bioallied Sci. 2012, 4, S252-S255. [CrossRef] [PubMed]

102. Alhusein, N.; Blagbrough, I.S.; Beeton, M.L.; Bolhuis, A.; De Bank, P.A. Electrospun zein/pcl fibrous matrices release tetracycline in a controlled manner, killing staphylococcus aureus both in biofilms and ex vivo on pig skin, and are compatible with human skin cells. Pharm. Res. 2016, 33, 237-246. [CrossRef] [PubMed]

103. Alhusein, N.; Blagbrough, I.S.; De Bank, P.A. Zein/polycaprolactone electrospun matrices for localised controlled delivery of tetracycline. Drug Deliv.Transl. Res. 2013, 3, 542-550. [CrossRef] [PubMed]

104. Alhusein, N.; De Bank, P.A.; Blagbrough, I.S.; Bolhuis, A. Killing bacteria within biofilms by sustained release of tetracycline from triple-layered electrospun micro/nanofibre matrices of polycaprolactone and poly(ethylene-co-vinyl acetate). Drug Deliv. Transl. Res. 2013, 3, 531-541. [CrossRef] [PubMed]

105. Alhusein, N.; Blagbrough, I.S.; De Bank, P.A. Electrospun matrices for localised controlled drug delivery: Release of tetracycline hydrochloride from layers of polycaprolactone and poly(ethylene-co-vinyl acetate). Drug Deliv. Transl. Res. 2012, 2, 477-488. [CrossRef] [PubMed]

106. Alhusein, N.; De Bank, P.; Blagbrough, I.S. Polycaprolactone electrospun nanofibers for controlled drug delivery. In The Encyclopedia of Biomedical Polymers and Polymeric Biomaterials; Mishra, M., Ed.; CRC Press: Boca Raton, FL, USA, 2015; Volume 7, pp. 5239-5249.

107. Liu, W.; Wang, Y.; Yao, J.; Shao, Z.; Chen, X. Tamoxifen-loaded silk fibroin electrospun fibers. Mater. Lett. 2016, 178, 31-34. [CrossRef]

108. Stygar, D.; Muravitskaya, N.; Eriksson, B.; Eriksson, H.; Sahlin, L. Effects of serm (selective estrogen receptor modulator) treatment on growth and proliferation in the rat uterus. Reprod. Biol. Endocrinol. 2003, 1, 40. [CrossRef] [PubMed]

109. Osborne, C.K.; Zhao, H.; Fuqua, S.A.W. Selective estrogen receptor modulators: Structure, function, and clinical use. J. Clin. Oncol. 2000, 18, 3172-3186. [CrossRef] [PubMed]

110. Souza, S.O.L.; Cotrim, M.A.P.; Oréfice, R.L.; Carvalho, S.G.; Dutra, J.A.P.; de Paula Careta, F.; Resende, J.A.; Villanova, J.C.O. Electrospun poly(E-caprolactone) matrices containing silver sulfadiazine complexed with $\beta$-cyclodextrin as a new pharmaceutical dosage form to wound healing: Preliminary physicochemical and biological evaluation. J. Mater. Sci. Mater. Med. 2018, 29, 67. [CrossRef] [PubMed]

111. Muangman, P.; Pundee, C.; Opasanon, S.; Muangman, S. A prospective, randomized trial of silver containing hydrofiber dressing versus $1 \%$ silver sulfadiazine for the treatment of partial thickness burns. Int. Wound J. 2010, 7, 271-276. [CrossRef] [PubMed]

112. Aytac, Z.; Uyar, T. Core-shell nanofibers of curcumin/cyclodextrin inclusion complex and polylactic acid: Enhanced water solubility and slow release of curcumin. Int. J. Pharm. 2017, 518, 177-184. [CrossRef] [PubMed]

113. Sun, X.Z.; Williams, G.R.; Hou, X.X.; Zhu, L.M. Electrospun curcumin-loaded fibers with potential biomedical applications. Carbohydr. Polym. 2013, 94, 147-153. [CrossRef]

114. Sudakaran, S.V.; Venugopal, J.R.; Vijayakumar, G.P.; Abisegapriyan, S.; Grace, A.N.; Ramakrishna, S. Sequel of $\mathrm{MgO}$ nanoparticles in PLACL nanofibers for anti-cancer therapy in synergy with curcumin/ $\beta$-cyclodextrin. Mater. Sci. Eng. C 2017, 71, 620-628. [CrossRef]

115. Xie, C.; Li, X.; Luo, X.; Yang, Y.; Cui, W.; Zou, J.; Zhou, S. Release modulation and cytotoxicity of hydroxycamptothecin-loaded electrospun fibers with 2-hydroxypropyl- $\beta$-cyclodextrin inoculations. Int. J. Pharm. 2010, 391, 55-64. [CrossRef] 
116. Masoumi, S.; Amiri, S.; Bahrami, S.H. Pcl-based nanofibers loaded with ciprofloxacin/cyclodextrin containers. J. Text. Inst. 2018, 109, 1044-1053. [CrossRef]

117. Sousa, J.; Alves, G.; Oliveira, P.; Fortuna, A.; Falcão, A. Intranasal delivery of ciprofloxacin to rats: A topical approach using a thermoreversible in situ gel. Eur. J. Pharm. Sci. 2017, 97, 30-37. [CrossRef]

118. Zhou, J.; Wang, Q.; Lu, H.; Zhang, Q.; Lv, P.; Wei, Q. Preparation and characterization of electrospun polyvinyl alcoholstyrylpyridinium/ $\beta$-cyclodextrin composite nanofibers: Release behavior and potential use for wound dressing. Fibers Polym. 2016, 17, 1835-1841. [CrossRef]

119. Borbás, E.; Balogh, A.; Bocz, K.; Müller, J.; Kiserdei, É.; Vigh, T.; Sinkó, B.; Marosi, A.; Halász, A.; Dohányos, Z.; et al. In vitro dissolution-permeation evaluation of an electrospun cyclodextrin-based formulation of aripiprazole using $\mu$ flux ${ }^{\mathrm{TM}}$. Int. J. Pharm. 2015, 491, 180-189. [CrossRef] [PubMed]

120. Panichpakdee, J.; Pavasant, P.; Supaphol, P. Electrospinning of asiaticoside/2-hydroxypropyl- $\beta$-cyclodextrin inclusion complex-loaded cellulose acetate fiber mats: Release characteristics and potential for use as wound dressing. Polymer 2014, 38, 338-350. [CrossRef]

121. Aytac, Z.; Dogan, S.Y.; Tekinay, T.; Uyar, T. Release and antibacterial activity of allyl isothiocyanate/ $\beta$-cyclodextrin complex encapsulated in electrospun nanofibers. Colloids Surf. B Biointerfaces 2014, 120, 125-131. [CrossRef] [PubMed]

122. Vega-Lugo, A.C.; Lim, L.T. Controlled release of allyl isothiocyanate using soy protein and poly(lactic acid) electrospun fibers. Food Res. Int. 2009, 42, 933-940. [CrossRef]

123. Luo, X.; Zhang, H.; Chen, M.; Wei, J.; Zhang, Y.; Li, X. Antimetastasis and antitumor efficacy promoted by sequential release of vascular disrupting and chemotherapeutic agents from electrospun fibers. Int. J. Pharm. 2014, 475, 438-449. [CrossRef] [PubMed]

124. Vigh, T.; Démuth, B.; Balogh, A.; Galata, D.L.; Van Assche, I.; Mackie, C.; Vialpando, M.; Van Hove, B.; Psathas, P.; Borbás, E.; et al. Oral bioavailability enhancement of flubendazole by developing nanofibrous solid dosage forms. Drug Dev. Ind. Pharm. 2017, 43, 1126-1133. [CrossRef]

125. Shastri, V.P.; Sy, J.C. Modulation of Drug Release Rate from Electrospun Fibers. U.S. Patent US20080220054A1, 11 September 2008.

126. Kazsoki, A.; Szabó, P.; Domján, A.; Balázs, A.; Bozó, T.; Kellermayer, M.; Farkas, A.; Balogh-Weiser, D.; Pinke, B.; Darcsi, A.; et al. Microstructural distinction of electrospun nanofibrous drug delivery systems formulated with different excipients. Mol. Pharm. 2018. [CrossRef]

127. Filée, P.; Freichels, A.; Jéröme, C.; Aquil, A.; Colige, A.; Tateu, V.T. Chitosan-Based Biomimetic Scaffolds and Methods for Preparing the Same. U.S. Patent WO2011151225A1, 13 February 2011.

128. Puškárová, A.; Bučková, M.; Kraková, L.; Pangallo, D.; Kozics, K. The antibacterial and antifungal activity of six essential oils and their cyto/genotoxicity to human hel 12469 cells. Sci. Rep. 2017, 7, 8211. [CrossRef]

129. Finnemore, H. The essential oils. Nature 1927, 119, 920.

130. Toscano-Garibay, J.D.; Arriaga-Alba, M.; Sánchez-Navarrete, J.; Mendoza-García, M.; Flores-Estrada, J.J.; Moreno-Eutimio, M.A.; Espinosa-Aguirre, J.J.; González-Ávila, M.; Ruiz-Pérez, N.J. Antimutagenic and antioxidant activity of the essential oils of citrus sinensis and citrus latifolia. Sci. Rep. 2017, 7, 11479. [CrossRef] [PubMed]

131. Tonglairoum, P.; Chuchote, T.; Ngawhirunpat, T.; Rojanarata, T.; Opanasopit, P. Encapsulation of plai oil/2-hydroxypropyl- $\beta$-cyclodextrin inclusion complexes in polyvinylpyrrolidone (PVP) electrospun nanofibers for topical application. Pharm. Dev. Technol. 2014, 19, 430-437. [CrossRef] [PubMed]

132. Tonglairoum, P.; Ngawhirunpat, T.; Rojanarata, T.; Kaomongkolgit, R.; Opanasopit, P. Fabrication and evaluation of nanostructured herbal oil/hydroxypropyl- $\beta$-cyclodextrin/polyvinylpyrrolidone mats for denture stomatitis prevention and treatment. AAPS Pharm. Sci. Tech. 2016, 17, 1441-1449. [CrossRef] [PubMed]

133. Lin, L.; Dai, Y.; Cui, H. Antibacterial poly(ethylene oxide) electrospun nanofibers containing cinnamon essential oil/beta-cyclodextrin proteoliposomes. Carbohydr. Polym. 2017, 178, 131-140. [CrossRef] [PubMed]

134. Wen, P.; Zhu, D.H.; Wu, H.; Zong, M.H.; Jing, Y.R.; Han, S.Y. Encapsulation of cinnamon essential oil in electrospun nanofibrous film for active food packaging. Food Control 2016, 59, 366-376. [CrossRef]

135. Wen, P.; Zhu, D.H.; Feng, K.; Liu, F.J.; Lou, W.Y.; Li, N.; Zong, M.H.; Wu, H. Fabrication of electrospun polylactic acid nanofilm incorporating cinnamon essential oil/ $\beta$-cyclodextrin inclusion complex for antimicrobial packaging. Food Chem. 2016, 196, 996-1004. [CrossRef] [PubMed] 
136. Feng, K.; Wen, P.; Yang, H.; Li, N.; Lou, W.Y.; Zong, M.H.; Wu, H. Enhancement of the antimicrobial activity of cinnamon essential oil-loaded electrospun nanofilm by the incorporation of lysozyme. RSC Adv. 2017, 7, 1572-1580. [CrossRef]

137. Munhuweyi, K.; Caleb, O.J.; van Reenen, A.J.; Opara, U.L. Physical and antifungal properties of $\beta$-cyclodextrin microcapsules and nanofibre films containing cinnamon and oregano essential oils. LWT Food Sci. Technol. 2018, 87, 413-422. [CrossRef]

138. Liu, Y.; Liang, X.; Zhang, R.; Lan, W.; Qin, W. Fabrication of electrospun polylactic acid/cinnamaldehyde/ $\beta$-cyclodextrin fibers as an antimicrobial wound dressing. Polymers 2017, 9, 464. [CrossRef]

139. Dhifi, W.; Bellili, S.; Jazi, S.; Bahloul, N.; Mnif, W. Essential oils' chemical characterization and investigation of some biological activities: A critical review. Medicines 2016, 3, 25. [CrossRef]

140. Dias Antunes, M.; da Silva Dannenberg, G.; Fiorentini, Â.M.; Pinto, V.Z.; Lim, L.T.; da Rosa Zavareze, E.; Dias, A.R.G. Antimicrobial electrospun ultrafine fibers from zein containing eucalyptus essential oil/cyclodextrin inclusion complex. Int. J. Biol. Macromol. 2017, 104, 874-882. [CrossRef] [PubMed]

141. Aytac, Z.; Kusku, S.I.; Durgun, E.; Uyar, T. Encapsulation of gallic acid/cyclodextrin inclusion complex in electrospun polylactic acid nanofibers: Release behavior and antioxidant activity of gallic acid. Mater. Sci. Eng. C 2016, 63, 231-239. [CrossRef]

142. Mascheroni, E.; Fuenmayor, C.A.; Cosio, M.S.; Di Silvestro, G.; Piergiovanni, L.; Mannino, S.; Schiraldi, A. Encapsulation of volatiles in nanofibrous polysaccharide membranes for humidity-triggered release. Carbohydr. Polym. 2013, 98, 17-25. [CrossRef]

143. Uyar, T.; Hacaloglu, J.; Besenbacher, F. Electrospun polystyrene fibers containing high temperature stable volatile fragrance/flavor facilitated by cyclodextrin inclusion complexes. React. Funct. Polym. 2009, 69, 145-150. [CrossRef]

144. Uyar, T.; Nur, Y.; Hacaloglu, J.; Besenbacher, F. Electrospinning of functional poly(methyl methacrylate) nanofibers containing cyclodextrin-menthol inclusion complexes. Nanotechnology 2009, 20, 125703. [CrossRef] [PubMed]

145. Uyar, T.; Hacaloglu, J.; Besenbacher, F. Electrospun polyethylene oxide (PEO) nanofibers containing cyclodextrin inclusion complex. J. Nanosci. Nanotechnol. 2011, 11, 3949-3958. [CrossRef] [PubMed]

146. Kayaci, F.; Uyar, T. Encapsulation of vanillin/cyclodextrin inclusion complex in electrospun polyvinyl alcohol (PVA) nanowebs: Prolonged shelf-life and high temperature stability of vanillin. Food Chem. 2012, 133, 641-649. [CrossRef]

147. Loong-Tak Lim, S.D.F.M.; Gopinadhan, P.; Jayasankar Subramanian, J. Alan Sullivan Encapsulation and Controlled Release of Volatile Organic Compounds. U.S. Patent US20160330952A1, 17 November 2016.

148. Aytac, Z.; Keskin, N.O.S.; Tekinay, T.; Uyar, T. Antioxidant $\alpha$-tocopherol/ $\gamma$-cyclodextrin-inclusion complex encapsulated poly(lactic acid) electrospun nanofibrous web for food packaging. J. Appl. Polym. Sci. 2017, 134, 44858. [CrossRef]

149. Aytac, Z.; Kusku, S.I.; Durgun, E.; Uyar, T. Quercetin/ $\beta$-cyclodextrin inclusion complex embedded nanofibres: Slow release and high solubility. Food Chem. 2016, 197, 864-871. [CrossRef]

150. Lemma, S.M.; Scampicchio, M.; Mahon, P.J.; Sbarski, I.; Wang, J.; Kingshott, P. Controlled release of retinyl acetate from $\beta$-cyclodextrin functionalized poly(vinyl alcohol) electrospun nanofibers. J. Agric. Food Chem. 2015, 63, 3481-3488. [CrossRef]

151. Oliveira, M.F.; Suarez, D.; Rocha, J.C.B.; de Carvalho Teixeira, A.V.N.; Cortés, M.E.; De Sousa, F.B.; Sinisterra, R.D. Electrospun nanofibers of polycd/PMAA polymers and their potential application as drug delivery system. Mater. Sci. Eng. C 2015, 54, 252-261. [CrossRef] [PubMed]

152. Costoya, A.; Ballarin, F.M.; Llovo, J.; Concheiro, A.; Abraham, G.A.; Alvarez-Lorenzo, C. Hmdso-plasma coated electrospun fibers of poly(cyclodextrin)s for antifungal dressings. Int. J. Pharm. 2016, 513, 518-527. [CrossRef] [PubMed]

153. Ouerghemmi, S.; Degoutin, S.; Tabary, N.; Cazaux, F.; Maton, M.; Gaucher, V.; Janus, L.; Neut, C.; Chai, F.; Blanchemain, N.; et al. Triclosan loaded electrospun nanofibers based on a cyclodextrin polymer and chitosan polyelectrolyte complex. Int. J. Pharm. 2016, 513, 483-495. [CrossRef] [PubMed]

154. Heydari, A.; Mehrabi, F.; Shamspur, T.; Sheibani, H.; Mostafavi, A. Encapsulation and controlled release of vitamin b2 using peracetyl- $\beta$-cyclodextrin polymer-based electrospun nanofiber scaffold. Pharm. Chem. J. 2018, 52, 19-25. [CrossRef] 
155. Nada, A.A.; Montaser, A.S.; Abdel Azeem, R.A.; Mounier, M.M. Eco-friendly gelatin-based electrospun fibers to control the release of chloramphenicol. Fibers Polym. 2016, 17, 1985-1994. [CrossRef]

156. Gross, B.J.; Branchflower, R.V.; Burke, T.R.; Lees, D.E.; Pohl, L.R. Bone marrow toxicity in vitro of chloramphenicol and its metabolites. Toxicol. Appl. Pharmacol. 1982, 64, 557-565. [CrossRef]

157. Schwinté, P.; Mariotte, A.; Anand, P.; Keller, L.; Idoux-Gillet, Y.; Huck, O.; Fioretti, F.; Tenenbaum, H.; Georgel, P.; Wenzel, W.; et al. Anti-inflammatory effect of active nanofibrous polymeric membrane bearing nanocontainers of atorvastatin complexes. Nanomedicine 2017, 12, 2651-2674. [CrossRef]

158. Bazhban, M.; Nouri, M.; Mokhtari, J. Electrospinning of cyclodextrin functionalized chitosan/pva nanofibers as a drug delivery system. Chin. J. Polym. Sci. 2013, 31, 1343-1351. [CrossRef]

159. Horst, A.; von Recum, T.T.; Julius, N.K.; Travis, S.; Iryna, M. Therapeutic Agent Delivery System and Method. U.S. Patent US20150010608A1, 8 January 2015.

160. Cecone, C.; Caldera, F.; Trotta, F.; Bracco, P.; Zanetti, M. Controlled release of deet loaded on fibrous mats from electrospun pmda/cyclodextrin polymer. Molecules 2018, 23, 1694. [CrossRef]

161. Celebioglu, A.; Uyar, T. Cyclodextrin nanofibers by electrospinning. Chem. Commun. 2010, 46, 6903-6905. [CrossRef]

162. Celebioglu, A.; Uyar, T. Electrospinning of nanofibers from non-polymeric systems: Polymer-free nanofibers from cyclodextrin derivatives. Nanoscale 2012, 4, 621-631. [CrossRef] [PubMed]

163. Celebioglu, A.; Uyar, T. Electrospun gamma-cyclodextrin ([gamma]-CD) nanofibers for the entrapment of volatile organic compounds. RSC Adv. 2013, 3, 22891-22895. [CrossRef]

164. Celebioglu, A.; Uyar, T. Electrospinning of polymer-free nanofibers from cyclodextrin inclusion complexes. Langmuir 2011, 27, 6218-6226. [CrossRef] [PubMed]

165. Celebioglu, A.; Umu, O.C.O.; Tekinay, T.; Uyar, T. Antibacterial electrospun nanofibers from triclosan/cyclodextrin inclusion complexes. Colloids Surf. B Biointerfaces 2014, 116, 612-619. [CrossRef] [PubMed]

166. Celebioglu, A.; Aytac, Z.; Kilic, M.E.; Durgun, E.; Uyar, T. Encapsulation of camphor in cyclodextrin inclusion complex nanofibers via polymer-free electrospinning: Enhanced water solubility, high temperature stability, and slow release of camphor. J. Mater. Sci. 2018, 53, 5436-5449. [CrossRef]

167. Celebioglu, A.; Yildiz, Z.I.; Uyar, T. Fabrication of electrospun eugenol/cyclodextrin inclusion complex nanofibrous webs for enhanced antioxidant property, water solubility, and high temperature stability. J. Agric. Food Chem. 2018, 66, 457-466. [CrossRef] [PubMed]

168. Celebioglu, A.; Yildiz, Z.I.; Uyar, T. Electrospun nanofibers from cyclodextrin inclusion complexes with cineole and p-cymene: Enhanced water solubility and thermal stability. Int. J. Food Sci. Technol. 2018, 53, 112-120. [CrossRef]

169. Aytac, Z.; Yildiz, Z.I.; Kayaci-Senirmak, F.; Tekinay, T.; Uyar, T. Electrospinning of cyclodextrin/linalool-inclusion complex nanofibers: Fast-dissolving nanofibrous web with prolonged release and antibacterial activity. Food Chem. 2017, 231, 192-201. [CrossRef]

170. Aytac, Z.; Yildiz, Z.I.; Kayaci-Senirmak, F.; San Keskin, N.O.; Kusku, S.I.; Durgun, E.; Tekinay, T.; Uyar, T. Fast-dissolving, prolonged release, and antibacterial cyclodextrin/limonene-inclusion complex nanofibrous webs via polymer-free electrospinning. J. Agric. Food Chem. 2016, 64, 7325-7334. [CrossRef]

171. Aytac, Z.; Yildiz, Z.I.; Kayaci-Senirmak, F.; San Keskin, N.O.; Tekinay, T.; Uyar, T. Electrospinning of polymer-free cyclodextrin/geraniol-inclusion complex nanofibers: Enhanced shelf-life of geraniol with antibacterial and antioxidant properties. RSC Adv. 2016, 6, 46089-46099. [CrossRef]

172. Celebioglu, A.; Yildiz, Z.I.; Uyar, T. Thymol/cyclodextrin inclusion complex nanofibrous webs: Enhanced water solubility, high thermal stability and antioxidant property of thymol. Food Res. Int. 2018, 106, 280-290. [CrossRef] [PubMed]

173. Yildiz, Z.I.; Celebioglu, A.; Kilic, M.E.; Durgun, E.; Uyar, T. Menthol/cyclodextrin inclusion complex nanofibers: Enhanced water-solubility and high-temperature stability of menthol. J. Food Eng. 2018, 224, 27-36. [CrossRef]

174. Celebioglu, A.; Kayaci-Senirmak, F.; Ipek, S.; Durgun, E.; Uyar, T. Polymer-free nanofibers from vanillin/cyclodextrin inclusion complexes: High thermal stability, enhanced solubility and antioxidant property. Food Funct. 2016, 7, 3141-3153. [CrossRef] 
175. Celebioglu, A.; Uyar, T. Antioxidant vitamin e/cyclodextrin inclusion complex electrospun nanofibers: Enhanced water solubility, prolonged shelf life, and photostability of vitamin E. J. Agric. Food Chem. 2017, 65, 5404-5412. [CrossRef]

176. Yildiz, Z.I.; Celebioglu, A.; Kilic, M.E.; Durgun, E.; Uyar, T. Fast-dissolving carvacrol/cyclodextrin inclusion complex electrospun fibers with enhanced thermal stability, water solubility, and antioxidant activity. J. Mater. Sci. 2018. [CrossRef]

177. Ultee, A.; Bennik, M.H.J.; Moezelaar, R. The phenolic hydroxyl group of carvacrol is essential for action against the food-borne pathogen bacillus cereus. Appl. Environ. Microbiol. 2002, 68, 1561-1568. [CrossRef] [PubMed]

178. Beena; Kumar, D.; Rawat, D.S. Synthesis and antioxidant activity of thymol and carvacrol based schiff bases. Bioorg. Med. Chem. Lett. 2013, 23, 641-645. [CrossRef]

179. Yildiz, Z.I.; Celebioglu, A.; Uyar, T. Polymer-free electrospun nanofibers from sulfobutyl ether7-beta-cyclodextrin (SBE7- $\beta-C D$ ) inclusion complex with sulfisoxazole: Fast-dissolving and enhanced water-solubility of sulfisoxazole. Int. J. Pharm. 2017, 531, 550-558. [CrossRef]

180. Balogh, A.; Horváthová, T.; Fülöp, Z.; Loftsson, T.; Harasztos, A.H.; Marosi, G.; Nagy, Z.K. Electroblowing and electrospinning of fibrous diclofenac sodium-cyclodextrin complex-based reconstitution injection. J. Drug Deliv. Sci. Technol. 2015, 26, 28-34. [CrossRef]

181. Vigh, T.; Horváthová, T.; Balogh, A.; Sóti, P.L.; Drávavölgyi, G.; Nagy, Z.K.; Marosi, G. Polymer-free and polyvinylpirrolidone-based electrospun solid dosage forms for drug dissolution enhancement. Eur. J. Pharm. Sci. 2013, 49, 595-602. [CrossRef]

182. Yu, H.S.; Lee, J.M.; Youn, Y.S.; Oh, K.T.; Na, K.; Lee, E.S. $\gamma$-cyclodextrin-phenylacetic acid mesh as a drug trap. Carbohydr. Polym. 2018, 184, 390-400. [CrossRef] [PubMed]

183. Celebioglu, A.; Yildiz, Z.I.; Uyar, T. Electrospun crosslinked poly-cyclodextrin nanofibers: Highly efficient molecular filtration thru host-guest inclusion complexation. Sci. Rep. 2017, 7, 7369. [CrossRef] [PubMed]

184. Ma, M.; Li, D. New organic nanoporous polymers and their inclusion complexes. Chem. Mater. 1999, 11, 872-874. [CrossRef] 